Journal of the Scientific Agricultural Society of Finland

Vol. 51: $381-419,1979$

Maataloustieteellinen Aikakauskirja

\title{
RENAL RESPONSES OF REINDEER TO HIGH AND LOW PROTEIN DIET AND SODIUM SUPPLEMENT
}

Selostus: Rehun raakavalkuais- ja suolapitoisuuden vaikutus poron munuaistoimintaan

\section{A I A V A L T O N E N}

Department of Physiology, College of Veterinary Medicine, SF-00550 Helsinki 55, and

Department of Veterinary Medicine, University of Helsinki, SF-00710 Helsinki 71, Finland

To BE PRESENTED, WITH THE PERMISSION OF THE College of Veterinary Medicine, for public CRITICISM IN THE Semicircular AUditorium, Hämeentie 57, Helsinki, on October 6, 1979 AT 12 o'CLOCK. 
ISBN 951-9041-11-7

ISSN $0024-8853$ 


\section{Preface}

The present investigation has mainly been performed at the Department of Veterinary Medicine, University of Helsinki. First of all I owe my most sincere feelings of gratitude to the late head of the Department, ERKкi RAJAKosKi, Associate Professor, for his kind encouragement and support in this study. My thanks go also to the Acting Head of the Department, Docent EERo TANHUANPÄÄ, V.M.D., for his interest and constructive critisism of the work. Further I wish to express my sincere gratitude to Professor Samuli Sarajas, Head of the Department of Physiology, College of Veterinary Medicine, for valuable advice and for generously placing the facilities of the department at my disposal.

To Professor John C. S. Fray, Department of Physiology, University of Massachusetts Medical School, I am beholden for his interest and constructive criticism of the manuscript.

My warmest thanks are due to my friend and colleaque Docent LEA Eriksson, V.M.D., for her never failing encouragement and guidance throughout this investigation.

I wish to thank Mrs. Tuula Saalasti, Mrs. Alli Johansson and Mr. Urpo Koskinen for their excellent technical assistance.

I am also grateful to Mr. Antri Uusirauva, M.Sc., for his collaboration in the radioactive work and Mr. JUKKa SAlonen, Agr., for the computer programming.

The staff of the Department of Animal Husbandry and Viikki Experimental Farm, University of Helsinki have given their help in management of the reindeer in many occasions. I am very grateful for this assistance. I would also like to express my gratitude to Arvi VALMARI, Dr. Agr., Head of the Lapland Experimental Station, Rovaniemi, for placing the facilities of the Station at my disposal.

The English text has been revised by Mrs. Sevastiana Ruusamo, M.A. This investigation has been supported by grants from the Ministry of Agriculture in Finland.

Finally I wish to thank my husband MATTI and children HanNa and PeKKa for their support and patience during my work. 


\section{CONTENTS}

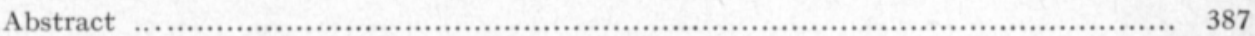

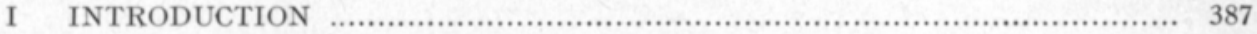

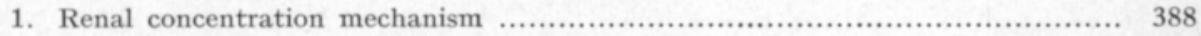

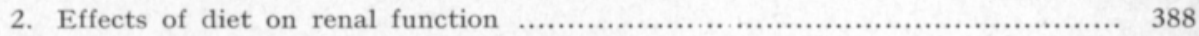

3. Special features of reindeer kidney …............................................... 390

4. Seasonal changes in metabolism of reindeer ...................................... 390

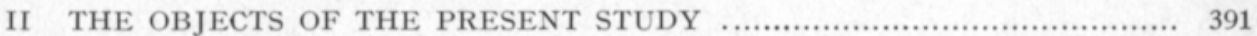

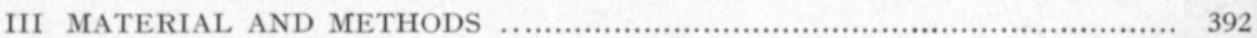

1. Experimental animals and their management ....................................... 392

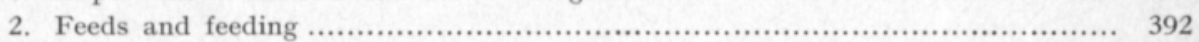

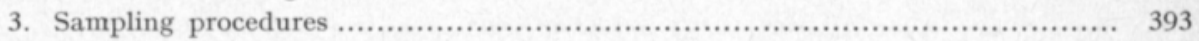

4. Measurement of the renal clearances of inulin and creatinine .................... 393

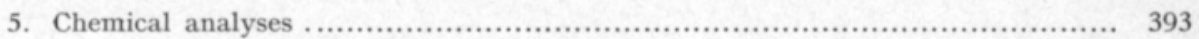

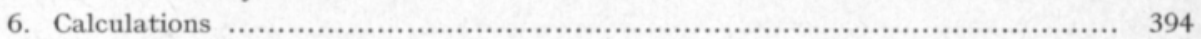

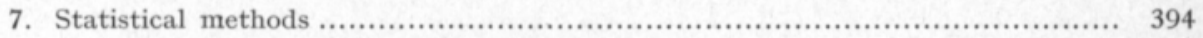

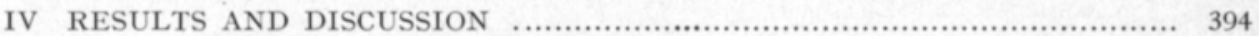

1. Creatinine clearance as a measure of glomerular filtration rate ................... 394

2. Renal responses to reducing dietary nitrogen ...................................... 396

3. Effects of increasing sodium chloride intake on renal function .................... 400

4. Effects of insufficient energy supply in the presence of low protein diet ....... 403

5. Lichen diet and renal function ............................................................ 405

6. Seasonal changes in renal excretion .................................................. 407

V GENERAL EVALUATION OF UREA CONSERVATION ....................... 410

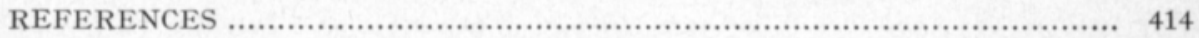

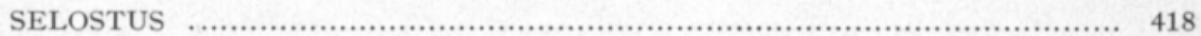





\title{
VAltonen, M. 1979. Renal responses of reindeer to high and low protein diet and sodium supplement. J. Scient. Agrig. Soc. Finl. 51: $381-419$.
}

\begin{abstract}
The effects of reducing dietary nitrogen and increasing sodium chloride intake on renal function were studied in reindeer in order so elucidate the extent of urea conservation and solute excretion by the reindeer kidney. The fall in plasma urea concentration and urea excretion on the low protein diet was accompanied by a significant reduction in the glomerular filtration rate (GFR) and urine osmolality. The fraction of filtered urea reabsorbed increased. However, the contribution of the fall of the GFR to restriction of urinary losses of urea was far more significant than the increase in fractional urea reabsorption.

The increase in sodium chloride intake reflected in icreased urinary sodium excretion, inducing a rise in urine osmolality on the low protein diet. Increased excretion of sodium was accompanied by decreased urea excretion. This interdependence of urea and sodium in urine excretion was particularly pronounced during the mating season in the autumn, when prominent retention of electrolytes and water was observed.

On low protein diet, when reindeer were exposed to cold, the energy intake proved insufficient. The use of body protein as energy source resulted in increased plasma urea values. The fractional reabsorption of urea decreased, but the GFR stayed low. The GFR seems to be unaffected by plasma urea concentrations but is in some way regulated by the intake of dietary protein. Also on lichen diet the intake was not sufficient to satisfy the energy requirements and the plasma urea concentrations increased. The urea excretion was still low due to a decreased GFR. The high moisture content of lichen caused an increase in the urine water excretion, but no increase occured in the solute excretion.

The rumen ammonia concentrations correlated significantly with the plasma urea concentrations, showing that urea is readily returned to the rumen in reindeer. The restriction of urea excretion on low protein intake contributes to the nitrogen economy and in reindeer it is brought about by a marked decrease in the GFR together with an increase in the urea reabsorption.
\end{abstract}

\section{Introduction}

The function of the kidney, sometimes regarded as a mainly excretory organ eliminating the nitrogenous wastes of the protein metabolism, should rather be considered regulatory. By controlling the concentration of metabolic end products the osmotic pressure and the ionic composition of the internal environment of the organism, the kidneys help to maintain the pshysiological intergrity of the extracellular fluid composition and volume. This is brought about by the operation of the basic renal mechanisms of glomerular filtration, tubular reabsorption and tubular secretion. 


\section{Renal concentration mechanism}

The remarkable ability of kidney to regulate daily water output is based on the countercurrent, and exchange systems of the renal medulla first presented by KuHN and RYFFel (1942). The anatomical arrangement and the physical properties of the tubules and blood vessels of the mammalian renal medulla make it possible for an osmotic concentration gradient to be formed from the cortex towards the medulla and papilla.

The formation of hypertonic urine by the mammalian kidney requires the action of the antidiuretic hormone $(\mathrm{ADH})$ and results from the passive osmotic equilibration of the tubular fluid flowing through the collecting ducts with the surrounding hyperosmotic interstitial fluid of the renal medulla and papilla. It has been generally accepted that sodium chloride and urea play a major part in the concentration process (KoKKo and RECTOR 1972; BERLINER 1976), although the precise mechanism by which the concentration gradient is built up in the medulla is still a matter of discussion (JAMIson and MafFLy 1976).

Urea accumulates in the medulla as a result of active reabsorption of sodium chloride by the thick ascending limb of the Henle's loop. In most mammals, urea constitutes about one half of the osmotically active solutes accumulated in the inner medulla during antidiuresis (ScHMIDT-NIELSEN and Robinson 1970). On high protein intake the contribution of urea may be elevated (Levinsky and Berliner 1959; Manitius et al. 1963), but in order to reach a maximal urine concentration, an elevated medullary sodium accumulation must also be invoked (de Rouffignac and Morel 1969). The micropuncture studies of Imbert and de Rouffignac (1976) have yielded evidence suggesting that sodium may contribute even in a larger proportion than urea to the concentration process in the kidney in desert rodents with high concentrating ability.

\section{Effects of diet on renal function}

Alterations in dietary protein or sodium chloride intake substantially affect the function of the mammalian kidney. The observation of GAmbLE et al. (1934) according to which the decreased concentrating ability of animals deprived of protein was referable to urea, has been confirmed by subsequent experiments (HENRIKX and EPSTEIN 1958).

In addition to decreased concentrating ability of the kidneys, protein deprivation causes significant changes in the urea reabsorption in many mammals. READ (1925) found practically no urea in the urine of camels on low protein diet. Retention of urea has also been found in sheep (SchmidT-NIELSEN et al. 1958) cattle (PHILlips et al. 1974) and goats (IDE 1971). The renal mechanisms of nonruminant species like man (MURDAUGH et al. 1958), dog (MANitius et al. 1963) and rat (CLAPP 1966) also respond but less pronouncedly to altered protein intake.

Protein metabolism in the ruminant involves the participation of urea cycle between blood and the rumen. It is well established that blood urea nitrogen is returned to the reticulum and rumen in sheep and cattle (reviewed by Houpt 1970). Urea enters the rumen in saliva (McDonald 1948; Houpt 
1959) and also by diffusion through the rumen wall (Houpt 1959; JuHÀsz 1965). In ruminants on low protein diet this is of great importance for the microbial protein synthesis and nitrogen economy of the host (Hungate 1966).

The kidney of mammals with restricted protein intake conserves nitrogen by decreasing the urea excretion markedly. The amount of urea excreted in the urine of mammals is determined both by the amount of urea filtered at the glomerulus and by the extent to which this urea is reabsorbed in the renal tubules.

The concentration of urea in the plasma is influenced by the level of nitrogen in the diet. In ruminants the blood urea rises with the increase of protein intake (PRESTON et al. 1965). The plasma concentration of urea largely determines the amount of urea filtered at the glomerulus. McIntrre and WiLLIAmS (1970) have reported a linear relationship between urea excretion and plasma urea concentration in sheep, but according to Cocimano and LENG (1967) the relationship is sigmoidal. The urine flow rate has also been shown to be related to the urea excretion (Cocimano and Leng 1967).

Many authors have reported in sheep a fall in glomerular filtration rate associated with decreased dietary protein intake (GANs and MERcer 1962; McIntyre and Williams 1970; Rabinowitz et al. 1973). However, no changes of glomerular filtration related to the diet could be observed by ScHMiDTNielsen et al. (1958) or Maloiy and Scott (1969).

The reabsorption of urea is thought to be passive, the urea diffusing down a favourable concentration gradient from the tubular urine into the blood. However, since a marked increase in the urea reabsorption, despite of decreased urine to plasma urea concentration ratio, was demonstrable in camel and sheep fed a low protein diet (Schmidt-Nielsen et al. 1957 and 1958) it was suggested that renal reabsorption of urea may not entirely depend on passive diffusion. Because, in these studies, no significant relation was found between the urea clearance and plasma urea concentration or the glomerular filtration rate, the retention of urea on low protein diets was attributed to active transport of urea or changes in tubular permeability. Also an increase in the permeability of the collecting ducts to urea has been suggested (RABINowitz et al. 1973).

Although the idea of active regulation of urea excretion has received some support, as reviewed by Thurau, VALtin and Schnermann (1968), there are studies (McIntyre and Williams 1970; ScotT and Mason 1970) revealing no evidence of an active urea transport mechanism restricting the urea excretion in ruminants on low protein diet.

Alterations in salt intake apparently have a noticeable effect on the renal function and the distribution pattern of sodium chloride and urea in the renal medulla. The results of Schmidt-Nielsen and O'Dell (1959) suggest that there is an interdependence of urea and electrolytes in the production of concentrated urine: the osmotic concentration in renal tissue and urine of the animal on normal protein intake was to a large extent created by urea accumulation, whereas on low protein intake the sodium accumulation was more operative. The post-glomerular influence of alterations in salt intake on the 
urea excretion and reabsorption has been extensively discussed (ScHMIDTNielsen et al. 1961; Truniger and Schmidt-Nielsen 1964), but the ultimate mechanism remains to be settled. High intake of sodium has been noted to cause an increase in the GFR of sheep (PotTer 1961) and cattle (WEeth and Lesperance 1965; Bailey 1978).

\section{Special features of reindeer kidney}

The anatomy of reindeer kidney has been investigated by SPERBER (1944). $\mathrm{He}$ found that in reindeer kidney the cortex is relatively thick, in relation to the medulla, the ratio being $1: 1$. The ratio of the volumes of cortex and medulla is 10: 1. The inner medulla is very low, containing only few long looped nephrons, compared to the kidneys of other domesticated ruminants. VALTONEN and ERIKSSON (1977) compared the relation of medullary and cortical heights of a pair of reindeer kidney with sheep kidney and found that the relation in reindeer was 0.86 and in sheep 2.33. They also found that reindeer kidney exhibits a limited capacity to concentrate urine or the excrete a solute load.

In mammals there is a close relationship between the relative thickness of renal medulla and concentrating ability (Schmidt-NielseN and O'DeLL 1961) and the unability of reindeer to excrete high osmolal urine in comparison with other ruminants is presumably related to the anatomical construction of the kidney. These data accord with Sperber's (1944) observation that the relative thickness of the renal medulla of a species is related to its diet and habitat.

MacFARLAne (1970/71) suggested that reindeer originate from wet regions, where water was readily available and the concentration of urine less important. In any case reindeer diet, consisting of lush green vegetation in the summer and mineral deficient lichen in the winter, may contain over 70 per cent water (Persson 1969). MacFarlane (1970/71) as well as Valtonen and Eriksson (1977) observed that reindeer are relatively resistant to antidiuretic hormone, reguiring a dose of $\mathrm{ADH}$ ten times as high as that needed for sheep to cause antidiuresis. This, too, supports the view that reindeer is not an animal adapted to water conservation.

\section{Seasonal changes in metabolism of reindeer}

The winter diet of freely grazing reindeer consists chiefly of lichen low in crude protein and minerals (STEEN 1968), while in the summer grass, sedges and decidious vegetation of high nutritive value is available for the animals (SkJEnneberg and Slagsvold 1968). Several studies show that wild reindeer are in poor nutritional status in the winter (Afanasev 1964; Dieterich and LUick 1971; CAMERON and LUICK 1972; HYVÄRINEN et al. 1975 and 1977). Seasonal changes in water metabolism of reindeer allowed to forage the native vegetation have been reported by CAMERoN and Luick (1972). They noted an increase in total water volume in the winter and simultaneous loss of body solids, while in the summer the water volume was reduced. The mean water flux rates were highest late in the spring and lowest in the early winter. 
On lichen diet, reindeer are likely to be in a negative nitrogen balance (Nordfelt et al. 1961) and loss of weight in the course of one winter may exceed by 10 per cent (PoIJÄrvi 1945; CAMEron and Luick 1972). Marked seasonal changes in the energy and nitrogen intake have also been found in reindeer reared on a high plane of nutrition (McEwAN and WHITEHEAD 1970), the caloric intake being $35-45$ per cent lower in the winter than during the summer growth period. Reindeer seem to follow a cyclic pattern of growth, losing weight in the winter even in favorable conditions (SKJENNEBERG and Slagsvold 1968).

The information available on renal responses of reindeer to alterations in diet is very limited. The findings in sheep and rat that urea concentrations in the medulla can be much higher than in the urine on low protein diet (Schmidt-Nielsen and O'Dell 1959; Truniger and Schmidt-Nielsen 1964) could not be verified in reindeer either in the autumn or winter (ERIKSSON and VAltonen 1974). However, Hove and Jacobsen (1975) studied renal excretion of urea in reindeer fed low and high protein diets and noted an average reabsorption of 93 per cent of the filtered urea on low protein diet while only 50 per cent of the filtered urea was reabsorbed on high protein diet. They calculated the reabsorbed urea to be a very significant contribution to the nitrogen economy of reindeer.

\section{The objects of the present study}

The effect of diet on renal function has been studied in domesticated ruminants with good renal concentrating ability but the mechanism by which renal excretion of urea is regulated in relation to protein intake is still open for discussion. Studies in a ruminant like reindeer which, despite a limited renal concentrating capacity, seems to be able to conserve urea on low protein diet, could further elucidate the effects of altered dietary protein intake on the function of mammalian kidney.

In view of the importance of renal conservation of nitrogen and minerals for the survival of reindeer during the winter and, considering the restricted information available on reindeer physiology, experimental studies on kidney function on different diets could provide more information on the adaptive responses of reindeer to environmental extremes. The results could also provide the information needed to develop the supplemental rations for reindeer. The following experiments were undertaken to elucidate the responses of reindeer kidney to alterations in dietary content of nitrogen and sodium chloride and the effects of season on renal function.

- Renal responses to reduced nitrogen and increased sodium chloride intake was studied by measuring the excretion and reabsorption of urea, electrolytes and solute-free water on a high and low protein diet with and without sodium chloride addition.

- Effects of climatic variations on renal responses were studied on low protein diet in the winter when the animals were exposed to cold. 
- Seasonal changes in renal responses were studied by comparing renal excretion of urea and electrolytes in the autumn and early winter to levels obtained in the late winter and spring. Effects of mating season were studied on high protein diet with salt load.

- Renal responses to lichen diet were studied in the winter and spring.

After the first experimental series, it proved necessary to test the effect of diet on the accuracy of creatinine clearance as a measure of glomerular filtration rate in reindeer. It was studied by comparing clearances of creatinine and inulin on both the high and the low protein diet.

\section{Material and methods}

\section{Experimental animals and their management}

Ten adult reindeer, three females and seven males, weighing 52-79 kg, were used in a total of 97 acute experiments. Of these experiments, 46 were performed on six animals in a high protein dietary state, 43 were on four animals in a low protein state and $\mathbf{8}$ on six animals on lichen diet. Besides this, weekly experiments were performed on two different reindeer couples during two autumns, one couple each autumn. When kept indoors, the animals were housed in individual stalls. The room temperature ranged from $+10^{\circ}$ to $20^{\circ} \mathrm{C}$. During two autumns and early winters the animals were housed in a common pen in the open and were taken to metabolic crates only during sampling times.

\section{Feeds and feeding}

The animals were fed twice daily and allowed free access to drinking water. The intake of water was measured. The high protein (HP) diet, the calculated crude protein content of dry matter being about 17 per cent, consisted of cut grass, dried green leaves and commercial pelleted reindeer mixture and protein concentrate, which provided 29-32 g nitrogen per day. The calculated crude protein content of the low protein (LP) diet was $2-4$ per cent. It consisted of a mixture of sugar (36 per cent), starch (32 per cent), ground straw (32 per cent) and a maximum of $400 \mathrm{~g}$ dried or frozen autumn leaves and hay daily. This diet provided 2.4-4.6 g nitrogen per day. Apart from nitrogen, these two rations were composed so as to be equal in energy contents providing about $3 \mathrm{Mcal}$ per day, the energy requirement for maintenance of reindeer in enclosure (PERsson 1967).

The HP and LP diets were given to the animals successively with and without an addition of mineral mixture, providing 6-10 g sodium chloride daily. The blood urea concentrations and urine excretion were followed weekly, but an acclimatization period of two or three weeks was allowed following change of diet before sampling for clearance measurements.

On lichen diet containing 3.0-4.4 per cent crude protein the animals were fed about $900 \mathrm{~g}$ dry matter per day. The lichen used in the winter period was contaminated with gravel and contained 48 per cent water, while the lichen used in the spring contained 64 per cent water. 


\section{Sampling procedures}

The sampling was performed in the morning before the animals were fed. Blood samples were taken from the jugular vein into centrifuge tubes containing heparin as anticoagulant. After centrifugation the plasma was separated and frozen until analyzed. Urine was collected in two hour samples via a rentention catheter in female reindeer. In male animals urine was collected to a drained plastic bag hung under the penis. The collection periods were determined by voluntary urination.

The spring trials with lichen were performed at the Lapland Experimental Station, Rovaniemi, where the urine was collected in 24 hour periods.

Rumen fluid samples for ammonia determination were taken with a stomach tube and pump. The animals were weighed at about two week intervals during the experimental periods.

\section{Measurement of the renal clearances of inulin and creatinine}

Comparison of endogenous creatinine clearance and inulin clearance was made by simultaneous determination of the glomerular filtration rate with endogenous creatinine and labelled inulin in two reindeer. [Hydroxymethyl ${ }^{14 \mathrm{C}}$ ] inulin was chosen for the purpose since it proved a good tracer of native inulin (MARLOW and SHEPPARD 1970). A constant infusion of $0.5 \mathrm{ml} / \mathrm{min}$ [hydroxymethyl ${ }^{14 \mathrm{C}}$ ] inulin (90 $\mu \mathrm{C}$ in $100 \mathrm{ml}$ saline) was carried out in the female reindeer after a priming dose of $12 \mathrm{ml}$. The constant infusion technique could not be used in the male reindeer because of its restless behaviour and only a priming dose of $50 \mathrm{ml}$ of the infusate was given. Still reasonably constant plasma levels were attained for about one hour, if an equilibration period of 30 min was allowed before sampling.

Urine was collected in 20 -min periods in the female, but in the male the periods, when determined by voluntary urination, ranged from 22 to $57 \mathrm{~min}$. Blood samples were collected from the jugular vein opposite to that the injection had been given in, as close to the midpoint of each urine collection period as possible. A total of 9 periods were collected, when the animals were on the HP diet and 10 periods on the LP diet.

\section{Chemical analyses}

The urea content of plasma and urine was determined by liberating ammonia with urease (ChANEY and MARBACH 1962). Ammonia in the rumen fluid was estimated immediately after sampling by the method of McCullough (1967). The blood and urine creatinine were analysed by the Technicon autoanalyser, and the radioactivity of samples containing [hydroxymethyl ${ }^{14 C}$ ] inulin was estimated by liquid scintillation counting. Sodium and potassium concentrations were determined by flame photometry and osmolality by the freezing point depression method with a Fiske osmometer.

\section{Calculations}

The glomerular filtration rate (GFR) was assayed as the renal clearance of creatinine. The quantity of urea filtered per minute was calculated GFR $\mathrm{x}$ 
plasma urea concentration. The urinary excretion rates of urea, sodium and potassium were calculated, as well as the urea clearance. The reabsorbed urea is the difference between filtered urea and excreted urea and is expressed as percentage of the filtered urea. Plasma osmolality of $290 \mathrm{mosm} / \mathrm{kg} \mathrm{H}_{2} \mathrm{O}$ was used for calculations of osmolal clearance $\left(\mathrm{C}_{\text {osm }}\right)$ and the difference between urine flow (V) and osmolal clearance represent the renal free water clearance $\left(\mathrm{C}_{\mathrm{H}_{2} \mathrm{O}}=\mathrm{V}-\mathrm{C}_{\mathrm{osm}}\right)$.

\section{Statistical methods}

The mean value of each parameter is given as the mean \pm standard deviation (S.D.) or standard error of mean (S.E.M.). The number of animals is indicated as $\mathrm{n}_{\mathrm{a}}$ and the number of observations as $\mathrm{n}$. Statistical evaluation of the differences in a given parameter between different diets was determined by the analysis of variance. Paired t-test was used in the comparison of inulin and creatinine clearances. The association between different parameters was determined by the regression analysis. The data processing was performed at the Computing Centre of the University of Helsinki.

\section{Results and discussion}

In this study the influence of salt on renal urea excretion proved to be very slight. Thus it seems justified to proceed from observations on all high protein and all low protein animals together. The observation on LP animals exposed to cold, on the other hand, differ to such a great extent from other results on the low protein diet that they are treated separately.

\section{Creatinine clearance as a measure of glomerular filtration rate}

In the present study endogenous creatinine was utilized for measurement of the glomerular filtration rate. In an attempt to validate the use of creatinine for measurement of the GFR in reindeer during altered nitrogen intake, simultaneous determinations of the GFR were made with [hydroxymethyl ${ }^{14 C}$ ] inulin and creatinine in reindeer on HP and LP diets.

\section{Observations}

Reduction of the dietary protein intake caused a reduction in the GFR measured with both inulin and creatinine. The mean values of inulin clearance in consecutive periods for both animals were $56.0 \pm 7.2 \mathrm{ml} / \mathrm{min}$ on the HP diet and $34.6 \pm 11.6$ on the LP diet. The values for creatinine clearance were $73.5 \pm 11.1$ and $42.2 \pm 16.6$, respectively. The difference between clearance values of HP and LP diets measured on both agents were significant ( $\mathrm{p}<0.001)$.

Analysis of the paired data of inulin and creatinine clearances (Fig. 1) demonstrated a highly significant correlation $(\mathrm{r}=0.919, \mathrm{p}<0.001)$ and a regression equation $\mathrm{y}=8.77+0.63 \mathrm{x}$ where $\mathrm{y}$ signifies clearance of creatinine and $\mathrm{x}$ [hydroxymethyl ${ }^{14 \mathrm{C}}$ ] inulin clearance. The mean ratio of the GFR determined with creatinine and [hydroxymethyl ${ }^{14 C}$ ] inulin was 1.25 on the HP 
Fig. 1. Correlation between creatinine and inulin clearances. The regression eguation is $\mathrm{y}=8.77+0.63 \mathrm{x}$ and $\mathrm{r}=$ 0.919 .

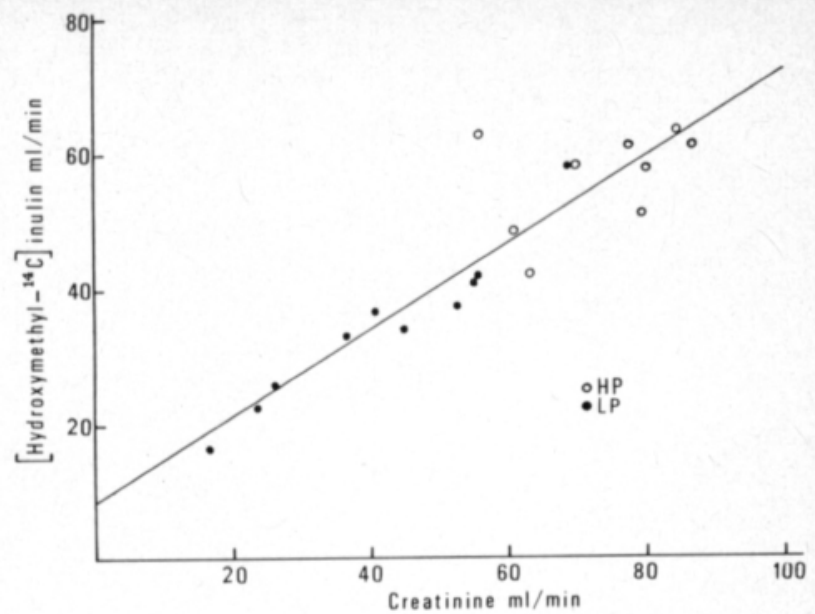

diet and 1.19 on the LP diet. Although the correlation of these two clearances was good, creatinine clearance overestimated the GFR. The differences is significant $(\mathrm{p}<0.01)$ as revealed by the paired t-test.

\section{Discussion}

The endogenous creatinine clearance is convenient for measuring the GFR, because it can be used without employing an infusion technique. This is of special importance in studies on wild animals in cold environment. In ruminants, creatinine clearance has been shown to correlate well with the inulin clearance (Poulsen 1957; Sellers 1958; Schmidt-Nielsen et al. 1958). The latter is generally accepted as an accurate measure of the GFR. Inulin is physiologically inert and entirely excreted by glomerular filtration with no renal tubular participation (SHANnon 1935). However, its use is limited because of the laborious techniques of analysis and the need of continuous infusion.

Variations between inulin and creatinine clearances have given evidence of some tubular secretion of creatinine both in man and animals (SPERBER and Sperber 1955; Poulsen 1957; Vogel 1962; Berlyne et al. 1964). The study of LADD et al. (1957) on glomerular and tubular function in sheep and goats indicates also tubular reabsorption of creatinine especially at high plasma concentrations. Since, in the present study on reindeer, the GFR decreased to very low values on the LP diet, reabsorption of creatinine was suspected. However, no reabsorption could be demonstrated by comparing simultaneous inulin and creatinine clearances. On both diets the creatinine clearances exceeded slightly the inulin clearances, reaching on the LP diet almost equal values.

These results agree with the finding of others (VOGEL 1962; SPERBER and SPERBER 1955; BERLYNE at al. 1964) that creatinine clearance overestimates the inulin clearance. However, the two clearances are highly correlated, making creatinine a suitable, in fact the only possible, substance for use in GFR estimations in the present work. The changes in creatinine clearance can thus be considered acceptable estimates of changes in the GFR. 


\section{Renal responses to reducing dietary nitrogen}

\section{Observations}

The plasma urea concentrations were significantly lower on the low protein diet than on the high protein diet (Table 1). The mean urine urea concentration, $224 \pm 76 \mathrm{mmol} / \mathrm{l}$, on the HP diet fell to the mean value of $14 \pm 12 \mathrm{mmol} / \mathrm{l}$ on the LP diet, resulting in a marked reduction in the urea urine to plasma $(\mathrm{U} / \mathrm{P})$ concentration ratios. The mean values of urea excretion and urine flow rates were also significantly lower when dietary protein intake was restricted (Fig. 2).

Table 1. Mean values ( \pm S.D.) of plasma urea concentrations, urea urine to plasma (U/P) concentration ratios and renal parameters for six animals on high protein (HP) diet and four animals on low protein (LP) diet. $\mathrm{n}=$ number of observations.

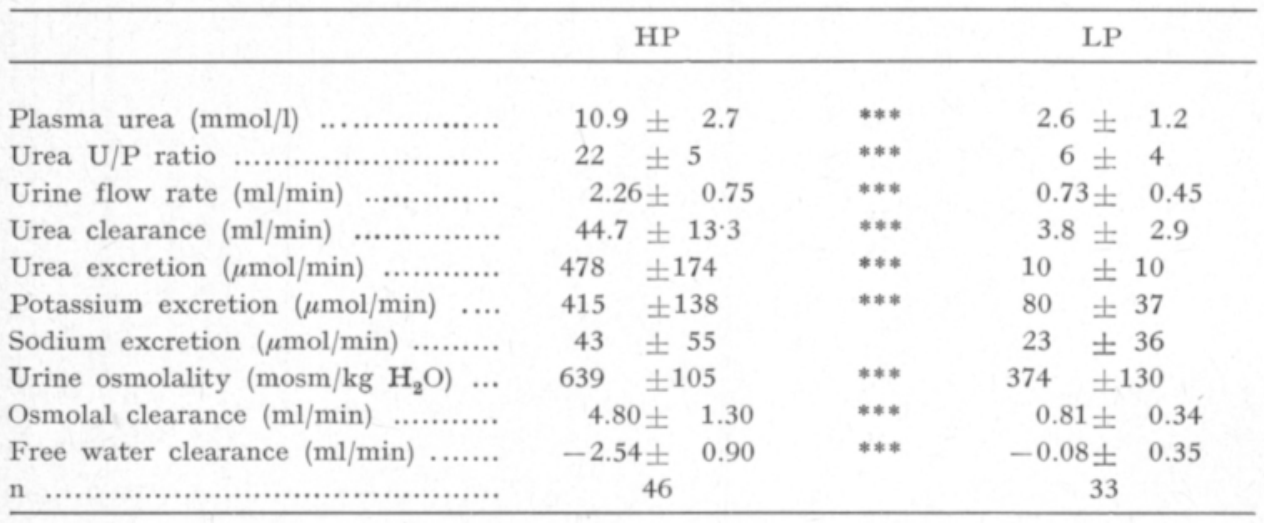

Significance of differences between means: $* * * \mathrm{p}<0.001$.

The HP diet contained slightly more sodium and had an inherently high potassium content. This was reflected in the urine excretion of the electrolytes. The urine osmolality was significantly higher on the HP diet than on the LP diet, and the osmolal clearance was only one fifth of the value on the HP diet. Simultaneously, the free water clearance became less negative. The water intake was $5.7 \pm 1.41\left(\mathrm{n}_{\mathrm{a}}=4, \mathrm{n}=38\right)$ on the HP diet and decreased to $2.7 \pm 0.81(\mathrm{n}=42)$ on the LP diet. Within the diets there was a highly significant negative correlation $(\mathrm{p}<0.001)$ between the urine flow rate and osmolality (Fig. 3), while the osmolality was positively correlated ( $\mathrm{p}<0.001$ ) to both potassium and urea excretion (Fig. 4). The ammonia concentrations in the rumen fluid average to $7.8 \pm 2.6 \mathrm{mmol} / 1\left(\mathrm{n}_{\mathrm{a}}=4, \mathrm{n}=14\right)$ in HP animals and $1.2 \pm 1.2 \mathrm{mmol} / \mathrm{l}(\mathrm{n}=15)$ in LP animals. The rumen ammonia concentrations were positively correlated to plasma urea concentrations within both diets $(\mathrm{p}<0.01)$.

The mean value of glomerular filtration rates and urea clearances were much reduced on the LP diet (Table 2). The quantity of filtered urea on the LP diet was only one tenth of that on the HP diet. Also the quantity of reabsorbed urea decreased significantly on the LP diet, although the percentage 


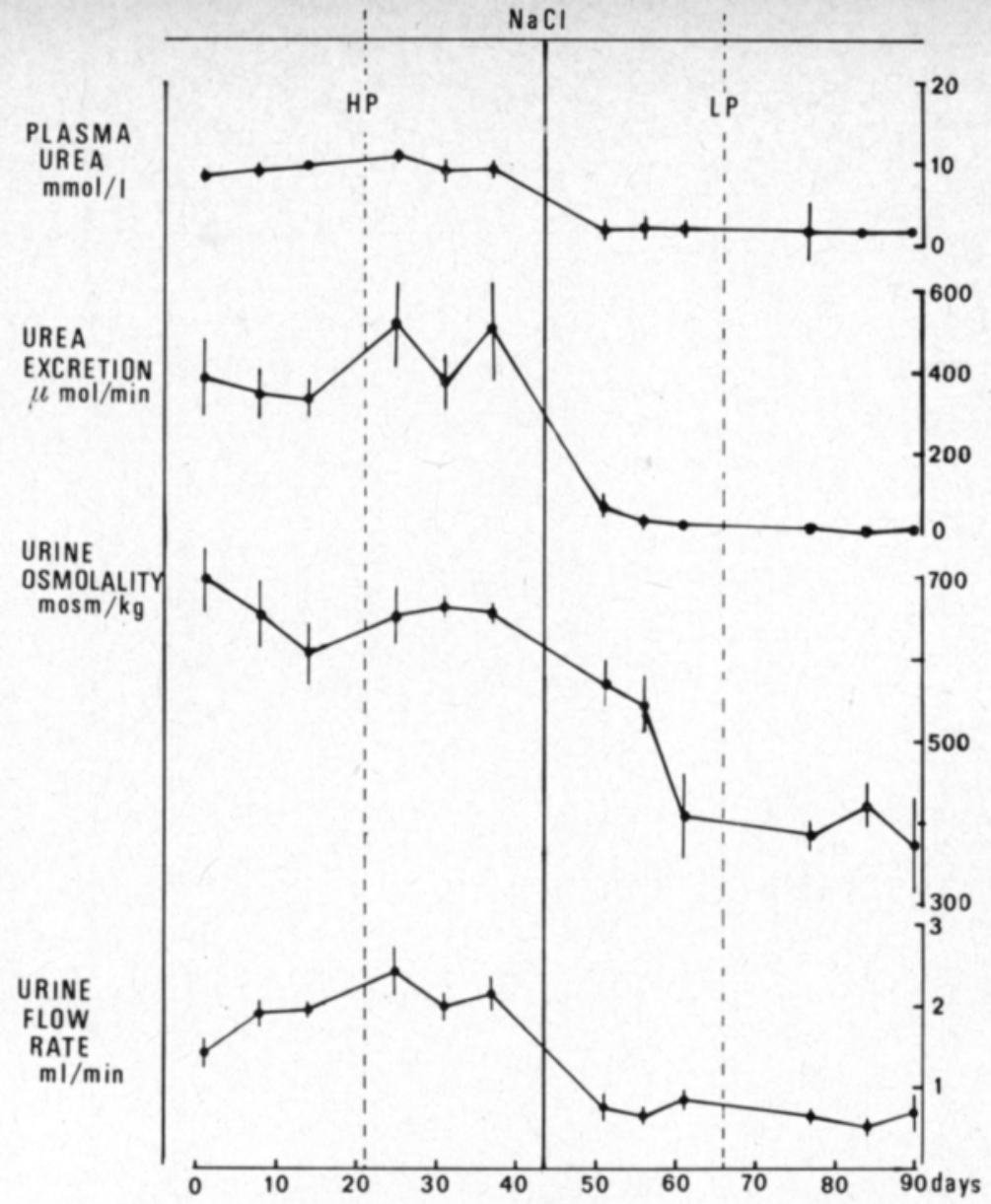

Fig. 2. Plasma urea concentrations, urea excretion rates, osmolalities and flow rates of urine during the high protein (HP) and low protein (LP) diets, showing the means \pm S.E.M. for 4 animals in 6 experiments. $\mathrm{NaCl}$ supplement was given between the days 22 and 66 .

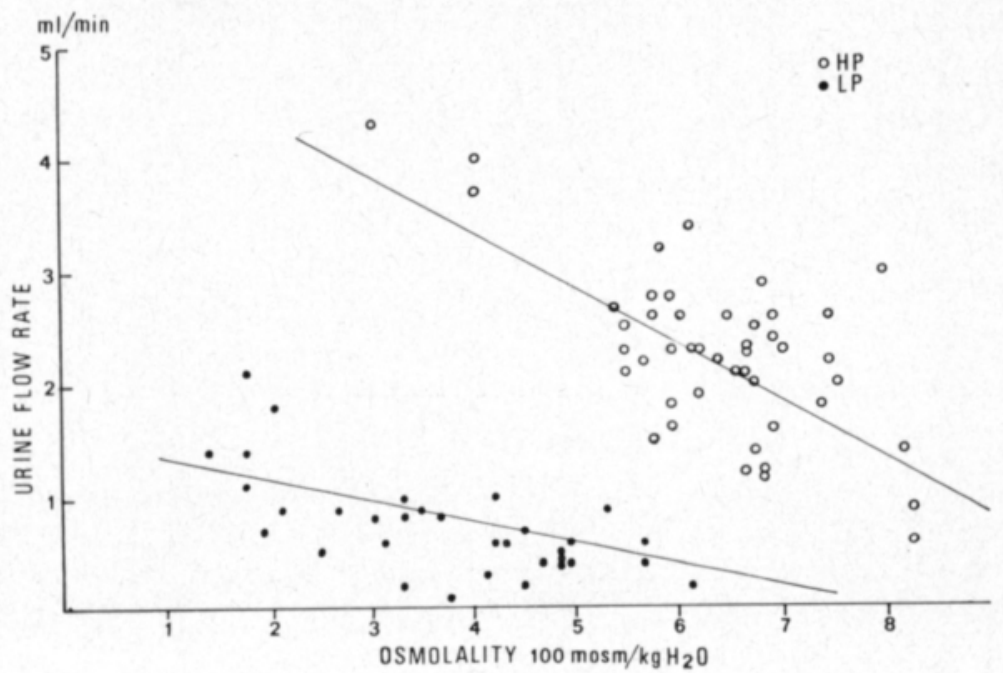

Fig. 3. Relationship between the flow rates and osmolalities of urine. On the HP diet the regression equation is $\mathrm{y}=5.295-0.005 \mathrm{x}$ and $\mathrm{r}=-0.660$ and on the LP diet $\mathrm{y}=1.607-0.002 \mathrm{x}$ and $\mathrm{r}=-0.668$. 


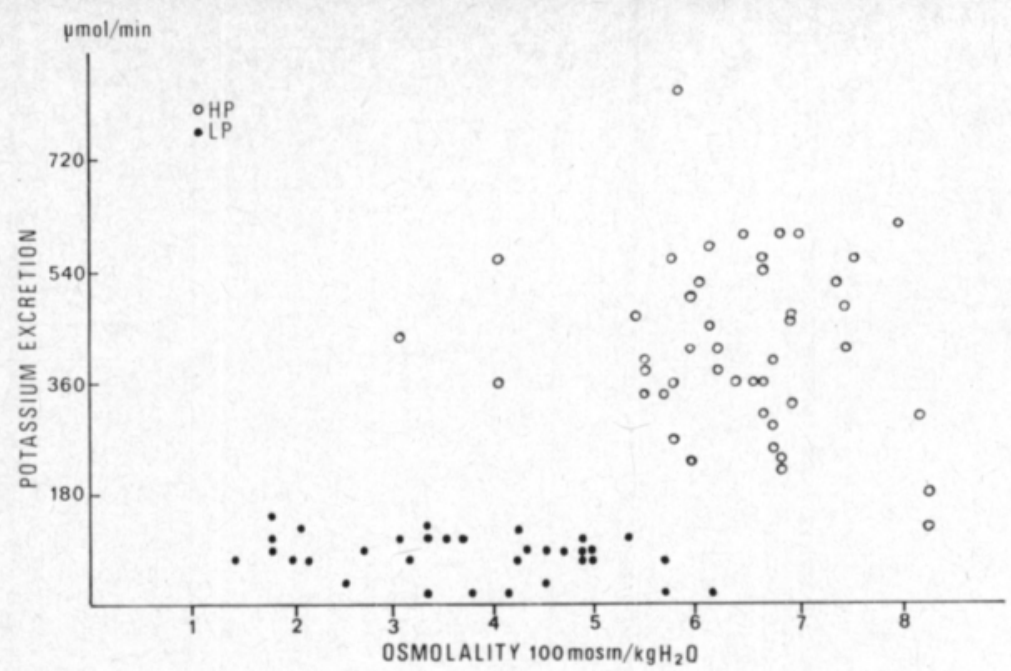

Fig. 4. (a, b). Relation of potassium (a) and

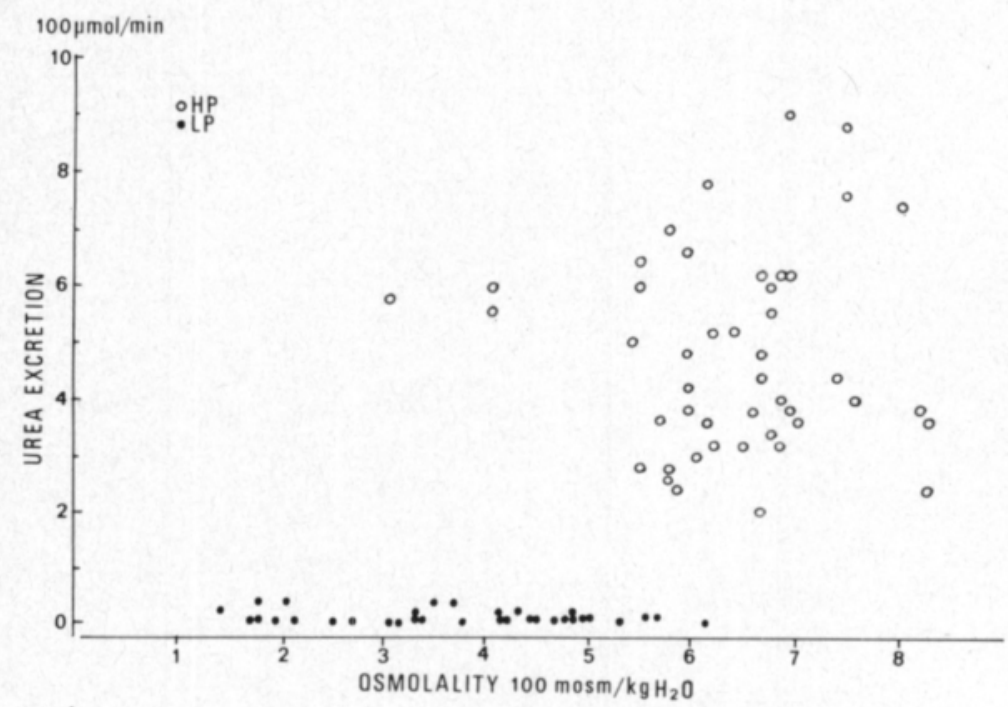

urea (b) excretion to urine osmolality on HP and LP diets.

Table 2. Mean values ( \pm S.D.) of glomerular filtration rates (GFR) and rates of urea filtration and reabsorption for four animals on HP diet and six animals on LP diet. $\mathrm{n}=$ number of observations.

\begin{tabular}{|c|c|c|c|}
\hline & HP & & LP \\
\hline GFR (ml/min) & $81.3 \pm 22.3$ & $* * *$ & $30.3 \pm 10.2$ \\
\hline Filtered urea $(\mu \mathrm{mol} / \mathrm{min})$................ & $857 \pm 337$ & $* * *$ & $87 \pm 49$ \\
\hline Reabsorbed urea $(\mu \mathrm{mol} / \mathrm{min}) \ldots \ldots \ldots$ & $395 \pm 213$ & $* * *$ & $76 \pm 40$ \\
\hline 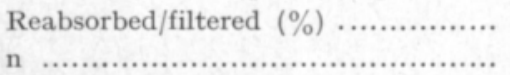 & $45 \pm 8$ & $* * *$ & $89 \pm 9$ \\
\hline
\end{tabular}

Significance of differences between means: ${ }^{* * *} \mathrm{p}<0.001$. 
of filtered urea reabsorbed increased. During the HP periods the weight of the animals remained unchanged or increased by $1-3 \mathrm{~kg}$. On the LP diet the reindeer lost $1-2 \mathrm{~kg}$ in four weeks.

\section{Discussion}

The plasma urea concentrations of the reindeer in the present study were significantly higher on the HP diet. They were of the same magnitude as in the reindeer studied by Hove and JACOBSEN (1975) who used diets comparable in protein contents. It has been demonstrated repeatedly that, when other factors are kept constant, the amount of ingested nitrogen strongly influence the plasma urea concentrations in ruminants (Livingston et al. 1962; Preston et al. 1965; Maloiy and Scott 1969; Biddle and Evans 1973; Manston et. al. 1975). This also applies to reindeer (McEwan 1968) as well as the reindeer of this study, where the protein content of the diet was altered, but the energy content was kept constant.

Before feeding the rumen ammonia concentrations followed the plasma urea concentrations in the reindeer of the present study. As for the turnover of plasma urea in ruminant, two main pathways must be considered. Urea is known to enter the rumen in saliva and by diffusion through the rumen wall, it is converted into ammonia and assimilated into microbial protein. On the other hand, urea is excreted mostly in the urine. Thus the plasma urea concentrations are also reflected in the urea excretion rates.

Urea constitutes a great part of the osmotically active solutes in urine, so that the osmolality and the osmolal clearance decreased along the decreased urea excretion. On the LP diet sodium and potassium largely determined the osmolality of the urine and the flow rate fell. With decreasing osmolal clearances the free water clearances increased.

The normally herbaceous diet of a ruminant places a relatively high potassium load on the kidneys and experiments on sheep have demonstrated, that a given quantity of potassium can be excreted in a smaller volume of urine on high protein intake (GANs and MERcer 1962). Also in the present study the potassium excretion rates were intimately related to urea excretion rates and osmolality. The negative correlation between flow rate and osmolality within the different diets (Fig. 3) indicates that the excretion rates of solutes were not affected by the urine flow rates.

Changes in the dietary protein supply strongly influenced the urine flow rate and this was reflected in water intake. The reindeer drank twice as much water on the HP diet as they did on the LP diet. In antidiuresis the urine osmolality is determined by the diet and the maximal urine concentrating capacity of the species (Schmidt-Nielsen and O'Dell 1961). The reindeer kidneys concentrate urine more when the nitrogen intake is high. Because of the limited concentrating capacity (VALTONEN and ERIKSSON 1977), however, reindeer must drink more to excrete the extra nitrogen load. On the $\mathrm{HP}$ diet the urine flow rate was higher despite of the increase in urine osmolality (Fig. 2).

The urine urea concentrations on both the HP and LP diets in the present study were lower than the respective concentrations in sheep fed comparable 
diets (Rabinowitz et al. 1973; Cocrmano and Leng 1967). Yet the excretion rate of urea was of the same magnitude as in sheep, since the urine flow rate of reindeer was much higher. Despite the lower concentrating ability, reindeer seem to posses a similar pattern of renal excretion of urea as other ruminants.

The percentage of filtered urea being reabsorbed in tubules was markedly increased in reindeer on the LP diet. This is in accordance with the previous report of reindeer on low protein diet (Hove and JACOBSEN 1975) and the earlier studies on domesticated ruminants (Schmidt-Nielsen et al. 1958; Livingston et al. 1962). However, in reindeer the actual quantity of urea reabsorbed on the LP diet was only one fifth of the quantity reabsorbed on the HP diet. Thus its contribution to the nitrogen economy of the animal on a low protein diet must be far less significant than the restriction of renal urea load brought about not only by the fall in plasma urea concentration but also by the marked decrease in glomerular filtration rate. Hove and JAcoBsen (1975) have also noted a fall in the GFR associated with reduction of dietary protein intake in reindeer, but they failed to consider its significance. The renal responses of reindeer to low protein feeding may be regarded as the reduction of the quantity of urea filtered in the glomeruli with an associated increase in the fraction of filtered urea reabsorbed.

The change in the GFR, associated with the change in dietary protein intake in this study on reindeer, was somewhat greater than that observed in sheep, cattle and goat (IDE 1971; Rabinowitz et al. 1973; Phillips et al. 1974). In reindeer kidney with its voluminous cortex, the capacity to modify the GFR may be stronger than in other domesticated ruminants. The existence of a quantitative difference between ruminant species in the ability to conserve urea has been suggested by Topps and ElLiot (1967) who found urea retention to be more efficient in cattle than sheep on the same low protein diet.

\section{Effects of increasing sodium chloride intake on renal function}

\section{Observations}

An increased dietary sodium intake increased significantly the sodium excretion rates on both the HP and LP diets (Table 3). On the HP diet the urea concentrations of plasma and urine urea excretion rates were unaffected by the increased salt intake. However, on the LP diet both the plasma concentrations and urea excretion rates were lower when salt intake was increased. On the HP diet the urine osmolality showed no significant change when the salt intake was increased, but on the LP diet the urine osmolality and the osmolal clearances increased, while the free water clearances decreased. On the HP diet there was a significant negative correlation $(\mathrm{p}<0.01)$ between sodium and urea excretion rates (Fig. 5). The mean values of water intake in liters on different diets were as follows:

$\begin{array}{cccc}\text { HP } & \mathrm{HP}+\mathrm{NaCl} & \mathrm{LP} & \mathrm{LP}+\mathrm{NaCl} \\ 5.5 \pm 1.3 & 5.8 \pm 1.0 & 2.5 \pm 0.8 & 2.9 \pm 0.6 \\ \mathrm{n}=17 & \mathrm{n}=21 & \mathrm{n}=21 & \mathrm{n}=21\end{array}$

The salt addition caused a significant $(\mathrm{p}<0.05)$ increase only on the LP diet. 
Table 3. Mean values ( \pm S.D.) of plasma urea concentrations, U/P concentration ratios and the renal parameters for six animals on HP diet and for four animals on LP diet with and without salt supplement. $\mathrm{n}=$ number of observations.

HP

$\mathrm{HP}+\mathrm{NaCl}$

LP

$\mathrm{LP}+\mathrm{NaCl}$

Plasma urea $(\mathrm{mmol} / \mathrm{l})$

$10.9 \pm 2.4$

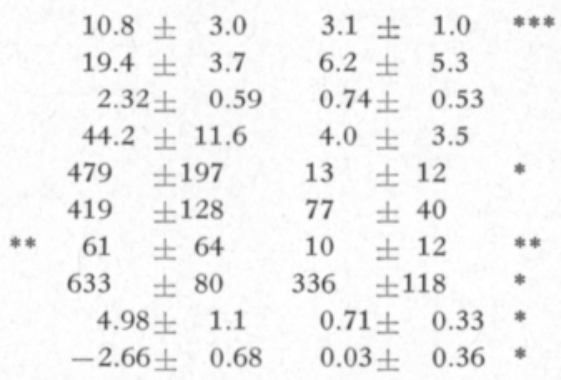

$1.8 \pm 1.1$

Urea $\mathrm{U} / \mathrm{P}$ ratio

$22.6 \pm 6.9$

Urine flow rate $(\mathrm{ml} / \mathrm{min}) \quad \ldots \ldots \ldots . .2 .19 \pm 0.93$

Urea clearance $(\mathrm{ml} / \mathrm{min}) \ldots \ldots \ldots \ldots . \quad 45.3 \pm 15.7$

Urea excretion $(\mu \mathrm{mol} / \mathrm{min}) \ldots \ldots .478 \quad \pm 144$

Potassium excretion $(\mu \mathrm{mol} / \mathrm{min}) \quad 411 \quad \pm 154$

Sodium excretion $(\mu \mathrm{mol} / \mathrm{min}) \ldots .20 \pm 27$

Urine osmolality $\left(\mathrm{mosm} / \mathrm{kg} \mathrm{H}_{2} \mathrm{O}\right) \quad 645 \pm 132$

Osmolal clearance $(\mathrm{ml} / \mathrm{min}) \quad \ldots \ldots . \quad 4.59 \pm 1.57$

Free water clearance $(\mathrm{ml} / \mathrm{min}) \ldots-2.39 \pm 1.13$

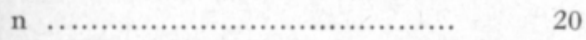

$20 \quad 26$

20

$5.2 \pm 2.3$

$0.71 \pm 0.32$

$3.4 \pm 1.6$

$5.3 \pm 2.4$

$84 \pm 32$

$42 \pm 51$

$434 \pm 129$

$0.96 \pm 0.32$

$-0.25 \pm 0.32$

Significance of differences between means of respective diet with and without $\mathrm{NaCl}:{ }^{* * *} \mathrm{p}<0.001,{ }^{* *} \mathrm{p}<0.01$, * $\mathrm{p}<0.05$.

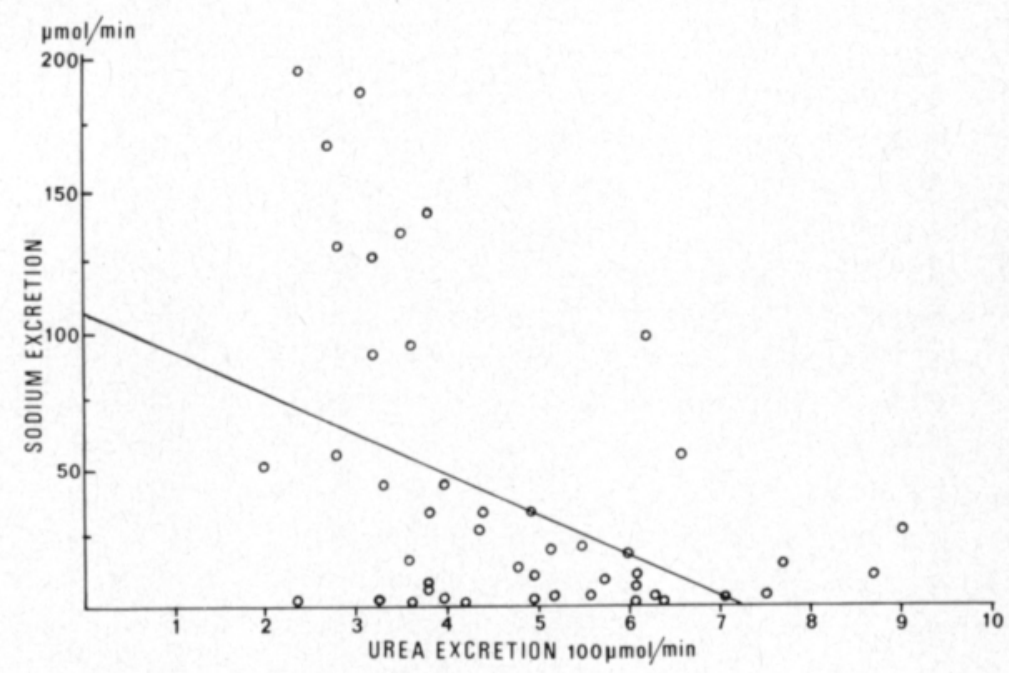

Fig. 5. Relationship between sodium and urea excretion rates the HP diet. The regression equation is $\mathrm{y}=-0.147 \mathrm{x}+107.5$ and $\mathrm{r}=-0.453$.

There were no significant changes in the mean values of the GFR or percentages of filtered urea reabsorbed when the salt intake was increased on the HP diet. On the LP diet, however, the urea filtration rate and the quantity of filtered urea reabsorbed were lower when the salt intake was increased (Table 4). 
Table 4. Mean values ( \pm S.D.) of glomerular filtration rates (GFR) and rates of urea filtration and reabsorption for six animals on HP diet and for four animals on LP diet with and without salt supplement. $\mathrm{n}=$ number of observations.

\begin{tabular}{|c|c|c|c|c|}
\hline diet & HP & $\mathrm{HP}+\mathrm{NaCl}$ & LP & $\mathrm{LP}+\mathrm{NaCl}$ \\
\hline GFR (ml/min) . & $83.0 \pm 25.2$ & $79.1 \pm 19.4$ & $31.0 \pm 10.0$ & $29.1 \pm 10.9$ \\
\hline Filtered urea $(\mu \mathrm{mol} / \mathrm{min}) \ldots \ldots$. & $898 \pm 322$ & $821 \pm 356$ & $104 \pm 46$ & $54 \pm 37$ \\
\hline Reabsorbed urea $(\mu \mathrm{mol} / \mathrm{min})$ & $402 \pm 145$ & $361 \pm 157$ & $92 \pm 40$ & $48 \pm 32$ \\
\hline Reabsorbed/filtered $(\%) \ldots \ldots .$. & $45 \pm 8$ & $44 \pm 8$ & $88 \pm 11$ & $89 \pm 5$ \\
\hline 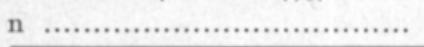 & 20 & 20 & 15 & 8 \\
\hline
\end{tabular}

Significance of differences between means of respective diet with and without $\mathrm{NaCl}:{ }^{*} \mathrm{p}<0.05$.

\section{Discussion}

The sodium excretion rates on both the HP and LP diets reflected the differences in dietary sodium chloride intake. The excretion rate of sodium on the LP diet without salt addition was, however, relatively high considering the almost total lack of sodium of this diet. Usually the kidney very efficiently reduces the amount of sodium excreted in the urine when sodium is in short supply.

Emotional disturbance of the animal, caused by sampling, may easily give rise to increased sodium excretion (Pickering 1965). It may have affected the sodium excretion rates also in this study, although the animals seemed comfortable and the sampling conditions were kept as constant as possible.

The salt addition did not influence the water intake very much, but increased salt intake caused a marked rise of the osmolality on the low protein diet with an associated increase in osmolal clearance and a decrease in free water clearance. This signifies the importance of sodium in the urine concentration mechanism of the kidney. When salt is added to the ration, sodium may contribute to a larger extent to the creation of the osmolal gradient in the kidney medulla and more concentrated urine is formed. If the salt intake in this trial had been higher, it would presumably have affected the water intake more, since the ability to excrete a solute load is limited in reindeer.

The negative correlation between the sodium and urea excretion rates on the HP diet is probably also traceable to the low concentrating capacity of reindeer kidney. When salt is added to the ration, the excretion of sodium reduces urea excretion. The ability to concentrate electrolytes is rather related to the thickness of the renal medulla than the ability to concentrate urea (SchMidT-Nielsen and O'Dell 1961).

It may be concluded that in animals with low concentrating capacity and low medulla, urea plays the most important part in the concentration process. This may also explain why the distribution of urea and electrolytes in renal medulla typical of low protein animals was not found in reindeer (ERIKSSON and Valtonen 1974).

The lower plasma urea consentrations together with decreased urea excretion rates on the LP diet with salt as compared to those on the LP diet without salt must be incidental and perhaps partly due to the small number of observations on that diet. Yet the differences between the concentrations 
are small and they do not reflect any significant changes in the GFR or urea reabsorption percentage between the two low protein diets.

High intake of salt by sheep and cattle has been reported to cause an increase in the GFR (PotTER 1961; BAILEY 1978), associated with the increase in the excretion of urea has been noted by WEETH and LESPERANCE (1965) and Schmidt-Nielsen et al. (1961). However, on moderate intake of salt, no effects on the GFR or urine urea excretion have been observed either in cattle (Phillips et al. 1974) or sheep (Ergene and Pickering 1978 b). In the present study the daily intake of $6-10 \mathrm{~g}$ of sodium chloride was not sufficient to alter the GFR or renal excretion of urea. Instead differences in urea filtration and reabsorption between the HP and LP diets (see section 2) were clearly associated with the change in nitrogen intake.

\section{Effects of insufficient energy supply in the presence of low protein diet}

\section{Observations}

There were two incidences along the present work, when a cold period of more than the degreeds centrigrade below zero encountered the animals housed in the outdoor pen. Since they seemed to suffer of insufficient supply of energy, the observations collected during these periods were handled separately as a low protein low energy (LP-LE) group (Table 5).

Table 5. Mean values ( \pm S.D.) of plasma urea concentrations, urea U/P concentration ratios and renal parameters for four animals on LP diet with low energy content (LP-LE). $\mathrm{n}=$ number of observations.

\begin{tabular}{|c|c|c|}
\hline$y$ & $\mathrm{LP}-\mathrm{LE}$ & \\
\hline Plasma urea $(\mathrm{mmol} / \mathrm{l})$........................ & $8.0 \pm 2.4$ & \multirow{11}{*}{ 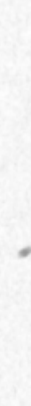 } \\
\hline 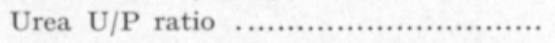 & $18.9 \pm 9.0$ & \\
\hline Urine flow rate $(\mathrm{ml} / \mathrm{min}) \quad \ldots \ldots \ldots \ldots \ldots . . .$. & $0.87 \pm 0.17$ & \\
\hline Urea clearance $(\mathrm{ml} / \mathrm{min})$.................. & $15.6 \pm 5.4$ & \\
\hline Urea excretion $(\mu \mathrm{mol} / \mathrm{min}) \quad \ldots \ldots \ldots \ldots \ldots$ & $123 \pm 45$ & \\
\hline Potassium excretion $(\mu \mathrm{mol} / \mathrm{min}) \quad \ldots \ldots \ldots .$. & $143 \pm 41$ & \\
\hline Sodium excretion $(\mu \mathrm{mol} / \mathrm{min}) \ldots \ldots \ldots \ldots \ldots$ & \pm 27 & \\
\hline Urine osmolality $\left(\operatorname{mosm} / \mathrm{kg} \mathrm{H}_{2} \mathrm{O}\right)$ & $540 \pm 87$ & \\
\hline Osmolal clearance $(\mathrm{ml} / \mathrm{min}) \quad \ldots \ldots \ldots \ldots \ldots . . . .$. & $1.61 \pm 0.36$ & \\
\hline Free water clearance $(\mathrm{ml} / \mathrm{min}) \ldots \ldots \ldots \ldots$ & $-0.74 \pm 0.28$ & \\
\hline 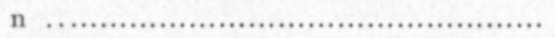 & 10 & \\
\hline
\end{tabular}

The plasma urea concentrations were significantly $(\mathrm{p}<0.001)$ increased in the LP-LE group in comparison with the results of the LP diet. There was a significant $(\mathrm{p}<0.001)$ rise in the urea $\mathrm{U} / \mathrm{P}$ concentration ratio and urea excretion. The urea clearance and urine osmolality were also increased. The rumen ammonia concentrations, 4.35 and $1.25 \mathrm{mmol} / 1$, measured only in two animals reflected the elevated plasma urea concentrations. Potassium excretion rates were higher $(p<0.01)$ in the LP-LE group than in the LP animals as were the osmolalities $(p<0.001)$ and associated osmolal clearances resulting in a fall of free water clearances. 
The GFR and the quantities of filtered and reabsorbed urea in four reindeer were as follows $(n=6)$ :

\begin{tabular}{|c|c|}
\hline $\mathrm{ml} / \mathrm{min})$ & $31.0 \pm$ \\
\hline Filtered urea $(\mu \mathrm{mol} / \mathrm{min})$ & \pm 136 \\
\hline eabsorbed urea $(\mu \mathrm{mol} / \mathrm{min})$ & 132 \\
\hline eabsorbed filtered $(\%), \ldots \ldots \ldots \ldots$ & 50 \\
\hline
\end{tabular}

The GFR was unaffected by the exposure to cold, but the percentage of filtered urea reabsorbed decreased significantly $(\mathrm{p}<0.001)$ from the values obtained on the LP diets to the level of the HP diet.

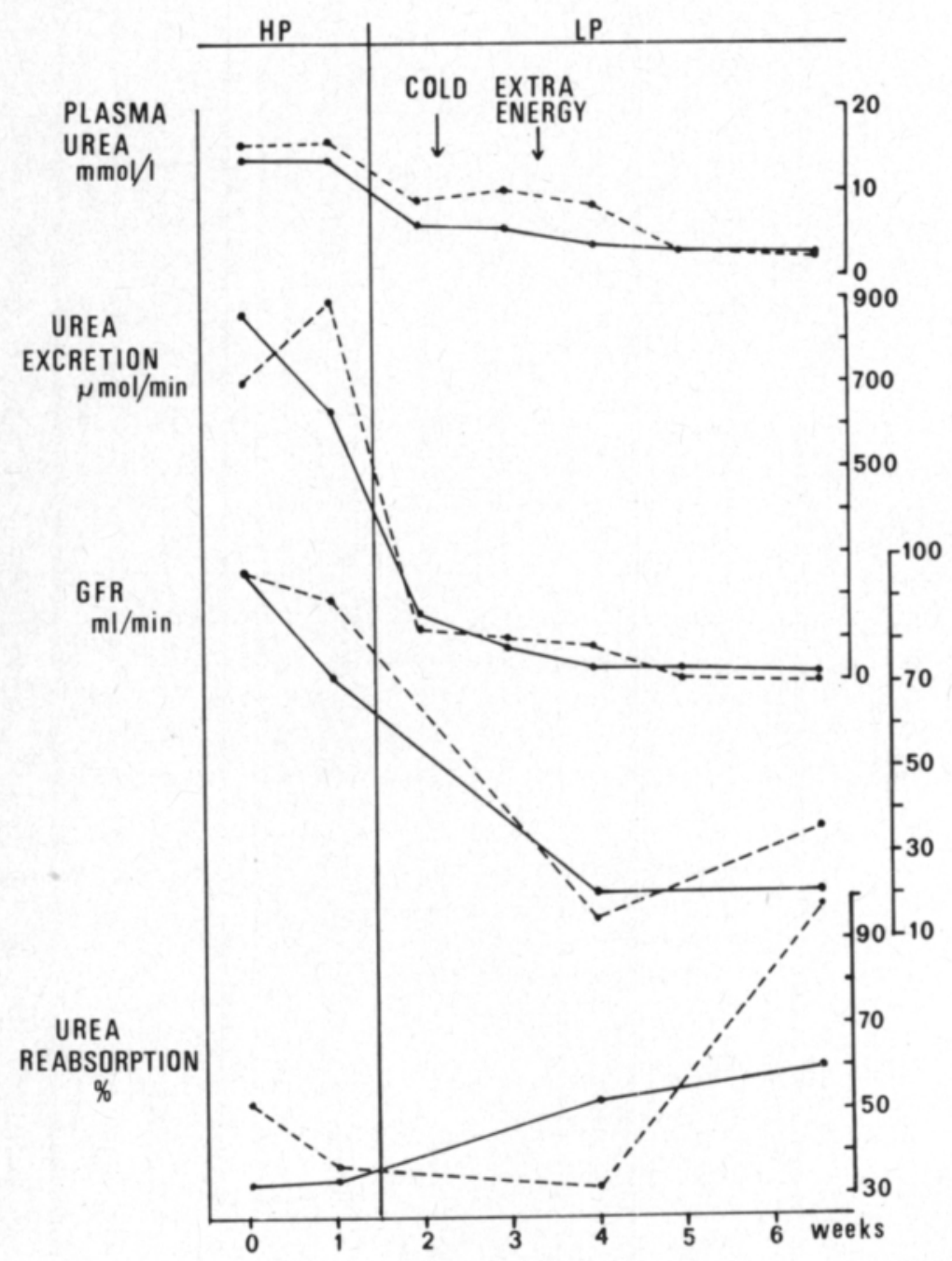

Fig. 6. Changes in plasma concentrations and urine excretion rates of urea, glomerular filtration rates (GFR) and persentages of filtered urea reabsorbed in a male (-) and a female (-) reindeer exposed to cold and given an extra energy supplement. 
Figure 6 shows the plasma concentrations and excretion rates of urea, the GFR and the percentages of filtered urea reabsorbed in two reindeer exposed to cold and given an extra supplement of energy (sugar $100 \mathrm{~g} /$ day).

The loss of weight during the LP-LE diet varied from 2 to $5 \mathrm{~kg}$ in four weeks.

\section{Discussion}

There was a marked increase in the plasma urea concentrations in reindeer exposed to cold in this study. The fall in ambient temperature seemed to increase the demand for energy of the animals given only the energy quantity of maintenance requirement in enclosure. According to McEwan and WhITEHEAD (1970), the estimated energy requirement for maintenance of reindeer in winter amounted to $5.5 \mathrm{Mcal} / \mathrm{day}$. This is far more than the reindeer were given in this study.

The increased level of plasma urea may be attributed to the utilization of body protein as energy source. A similar effect of limited energy intake on plasma urea level has been observed in deer (TEERI et al. 1958), cattle (IDE et al. 1967) and sheep (Leibholz 1970). Acute starvation may also result in elevated plasma urea values in sheep (FARREL et al. 1972; HARWEYer et al. 1973) and in reindeer (VAltonen, unpublished observations). The very high blood urea levels found in reindeer during gatherings for slaughter (ERIKSSON and VALtonen 1974; Hyvärinen et al. 1976) may be traceable to limited energy intake, as well as the high blood urea values found in reindeer by DiETERICH and LUICK (1971). In the present study, two reindeer were experimentally supplied with extra energy during the cold period. The blood urea values decreased promptly to the level typical of low protein diet with sufficient energy content. This also indicates that the elevated plasma urea levels were caused by insufficient access to energy.

The most remarkable finding on the $\mathrm{LP}-\mathrm{LE}$ diet was that the GFR values stayed on the same low level as on the LP diet and that they were unaffected by the evelevated plasma urea concentrations. This support the conclusion presented in the previous section that the main response of reindeer kidney to decreased dietary protein intake is the fall in the GFR. This response seems to be unaffected by the plasma urea concentrations. On the contrary, the percentage of filtered urea reabsorbed was decreased to the level typical of reindeer on HP diet. This fall in the reabsorption ratio was likely to be related to the elevated blood urea concentration. These results appear consonant with the finding of RABINOwITZ et al. (1973) that despite of increased plasma urea cencentrations in starved animals, i.e. sheep on a low protein diet, the GFR and urea excretion rates remained low.

\section{Lichen diet and renal function}

\section{Observations}

The mean values of the different parameter on lichen diet (Table 6) were very similar to those on $\mathrm{LP}-\mathrm{LE}$ diet presented in the previous section. Only potassium excretion rates were significantly $(p<0.001)$ lower. Between the 
results obtained on the two lichen diets differing in water content there were significant differences in potassium excretion, urine osmolality, osmolal clearance and free water clearance. Ingestion of lichen with 64 per cent moisture content resulted in urine osmolality below that of plasma and in positive free water clearance even if the animals had not drunk any water.

Table 6. Mean values ( \pm S.D.) of plasma urea concentrations, urea U/P concentration ratios and renal parameters for four animals on lichen diet of $64 \%$ moisture content and for two animals on lichen of $48 \%$ moisture content. $n=$ number of observations.

\begin{tabular}{|c|c|c|c|c|c|}
\hline & $64 \%$ & moisture & & $48 \%$ moisture & All lichen \\
\hline Plasma urea $(\mathrm{mmol} / \mathrm{l})$ & 6.6 & \pm 2.5 & & $8.9 \pm 0.8$ & $7.7 \pm 2.1$ \\
\hline 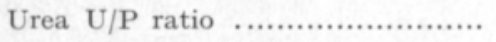 & 8 & \pm 3 & $*$ & $29 \pm 13$ & $19 \pm 14$ \\
\hline Urine flow rate $(\mathrm{ml} / \mathrm{min})$ & 0.7 & $9 \pm \quad 0.12$ & & $0.70 \pm 0.14$ & $0.71 \pm 0.13$ \\
\hline Urea clearance $(\mathrm{ml} / \mathrm{min}) \ldots \ldots \ldots \ldots \ldots$ & 6.4 & \pm 2.7 & * & $18.9 \pm 6.8$ & $12.6 \pm 8.2$ \\
\hline Urea excretion $(\mu \mathrm{mol} / \mathrm{min}) \ldots \ldots \ldots$ & 46 & \pm 39 & * & \pm 60 & $106 \pm 79$ \\
\hline Potassium excretion $(\mu \mathrm{mol} / \mathrm{min}) \ldots$ & 3 & \pm 1 & $* * *$ & \pm 39 & \pm 12 \\
\hline Sodium excretion $(\mu \mathrm{mol} / \mathrm{min}) \ldots \ldots \ldots$ & 2 & \pm 1 & & \pm 0 & \pm 1 \\
\hline Urine osmolality $\left(\mathrm{mosm} / \mathrm{kg} \mathrm{H_{2 }} \mathrm{O}\right)$. & 223 & \pm 137 & $* * *$ & $703 \pm 84$ & $463 \pm 277$ \\
\hline Osmolal clearance $(\mathrm{ml} / \mathrm{min}) \quad \ldots \ldots \ldots . .$. & 0.7 & $5 \pm \quad 0.45$ & $* *$ & $1.68 \pm 0.23$ & $1.15 \pm 0.66$ \\
\hline Free water clearance $(\mathrm{ml} / \mathrm{min}) \ldots \ldots$. & 0.1 & $6 \pm 0.40$ & $* * *$ & $-0.96 \pm 0.15$ & $-0.41 \pm 0.67$ \\
\hline n & & 4 & & 4 & 8 \\
\hline
\end{tabular}

Significance of differences between means of the two lichen diets: ${ }^{* *} \mathrm{p}<0.001,{ }^{* *} \mathrm{p}<0.01$, ${ }^{*} \mathrm{p}<0.05$.

The functions that affect the quantity of urea excreted were measured only in the group ingesting lichen with 48 per cent moisture content. The results are as follows $\left(\mathrm{n}_{\mathrm{a}}=2 \mathrm{n}=4\right)$ :

\begin{tabular}{|c|c|}
\hline GFR (ml/min) & $37.3 \pm$ \\
\hline Filtered urea $(\mu \mathrm{mol} / \mathrm{min})$ & $328 \pm 24$ \\
\hline Reabsorbed urea $(\mu \mathrm{mol} / \mathrm{min}) \quad \ldots$. & $148 \pm 19$ \\
\hline Reabsorbed/filtered $(\%)$.............. & $48 \pm 21$ \\
\hline
\end{tabular}

The rumen ammonia concentrations measured in the group ingesting lichen with 64 per cent moisture content were $4.31 \pm 1.24 \mathrm{mmol} / 1\left(\mathrm{n}_{\mathrm{a}}=4 \mathrm{n}=4\right)$.

\section{Discussion}

The similarity of the results on lichen diet and LP-LE indicates that reindeer on lichen diet also suffer from incufficient energy supply. Lichen diet should provide enough energy, since it is rich in easily digestible carbohydrates. Presumably the intake of lichen in this study was not great enough to maintain the energy requirements of the animals and they had to use body protein as source of energy. Freely grazing reindeer are likely to get into the same situation with similar concequences during heavy winters. Elevated blood urea concentrations in reindeer during the winter have been reported earlier (Afanasev 1964; Dieterich and Luick 1971; Eriksson and Valtonen 1974; 
HYVÄRINEN et al. 1975). The energy reguirements may be satisfied in reindeer on lichen diet if the intake is great enough, but in this study the palatability of lichen seem to have decreased perhaps due to insufficient adaptation of rumen microbes to lichen diet after previous trials with other rations.

In this study the lichen diet containing 64 per cent moisture resulted in decreased osmolality and positive free water clearance. The animals were in fact in water diuresis. Still, the urea clearance and urea excretion rate values were very low and no "washing out" of urea seem to have occurred, as happens in sheep during diuresis (Schmidt-Nielsen et al. 1958). The result is in consistency with the previous finding of VALTONEN and ERIKSSON (1977) that reindeer posses a good ability to excrete surplus water without losing solutes. Reindeer kidney contains only few long looped nephrons, but according to Martinez-Maldonado and Opava-stitzer (1978) these structures are not essential for the maximal generation of free water.

The GFR, measured only in reindeer fed lichen with 48 per cent moisture content, were on the same low level as on the LP diet. This corroborates the conclusion in the previous section, that reindeer respond to low protein intake with a fall in the GFR and the response is independent of blood urea concentration.

The percentage of filtered urea reabsorbed was 48 per cent. This equals the level in reindeer on the HP diet and on the LP-LE diet. The low reabsorption percentage was, also in the lichen trials, accompanied by high plasma urea values. The rumen ammonia concentrations, too, were relatively high considering the low nitrogen content of the lichen. The results on the LP-LE diet and the lichen diets suggest that, if reindeer are offered supplemental feed in the winter, the ration should be abundant with energy, whereas profusion of nitrogen is not necessary and may be even injurious, because it increases the need of drinking water.

\section{Seasonal changes in renal excretion}

\section{Observations}

The present experiments showed marked seasonal changes in electrolyte excretion. Sodium excretion rates were on the HP diet with salt supplement in the autumn, during October and November, significantly $(\mathrm{p}<0.001)$ lower than in the winter and spring (Fig. 7). Small decreases in potassium excretion rates and free water clearances were also observed in the autumn as compared to values in the spring. However, the changes were not statistically significant.

In order to get further light on the alterations occurring in the autumn, the renal excretion rates of urea and electrolytes were followed weekly during October and November in two females and two males under salt and nitrogen load (HP diet with salt). A clear-cut decline of sodium and potassium excretion occurred despite of the load, but the urea excretion rates and the values of free water clearances were fluctuating (Fig. 8).

In the autumn, in the presence of sodium retention urea excretion is increased. Considering both the values in the autumn and other times of the year 


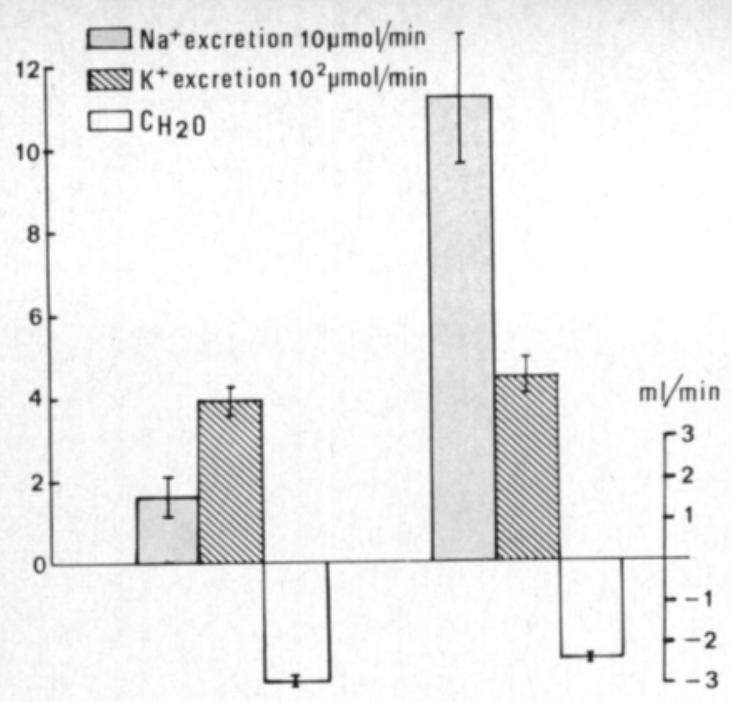

Fig. 7. Excretion rates of sodium, potassium and solute-free water, expressed as free water clearances, showing means \pm S.E.M. of 12 observations for four reindeer on the HP diet with $\mathrm{NaCl}$ during the reproductive period in the autumn and 14 observations for six reindeer during the non-reproductive period, winter and spring.

AUTUMN

SPRING

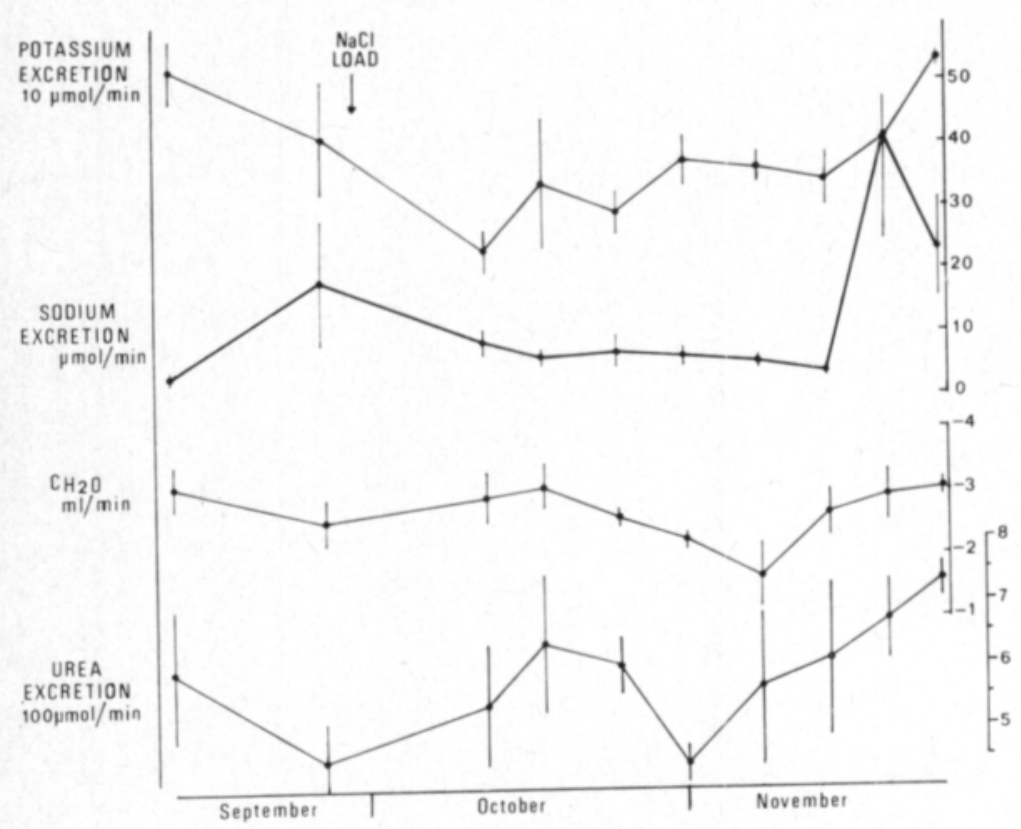

Fig. 8. Excretion rates of sodium, potassium and urea and free water clearances on the HP diet during the mating time in the autumn, showing the means \pm S.E.M. for four reindeer. Start of $\mathrm{NaCl}$ supplement is indicated.

the relationship on the HP diet with salt supplement could be best described by the equation $\mathrm{y}=\frac{28665}{\mathrm{x}}-19.6, \mathrm{r}=0.4961, \mathrm{p}<0.01$ (Fig. 9).

The LP diet was not given in the autumn, only in the winter and spring. However, on this diet significant $(p<0.05)$ increases in the flow rates and solute free water clearances were observable during the spring. (Fig. 10). 


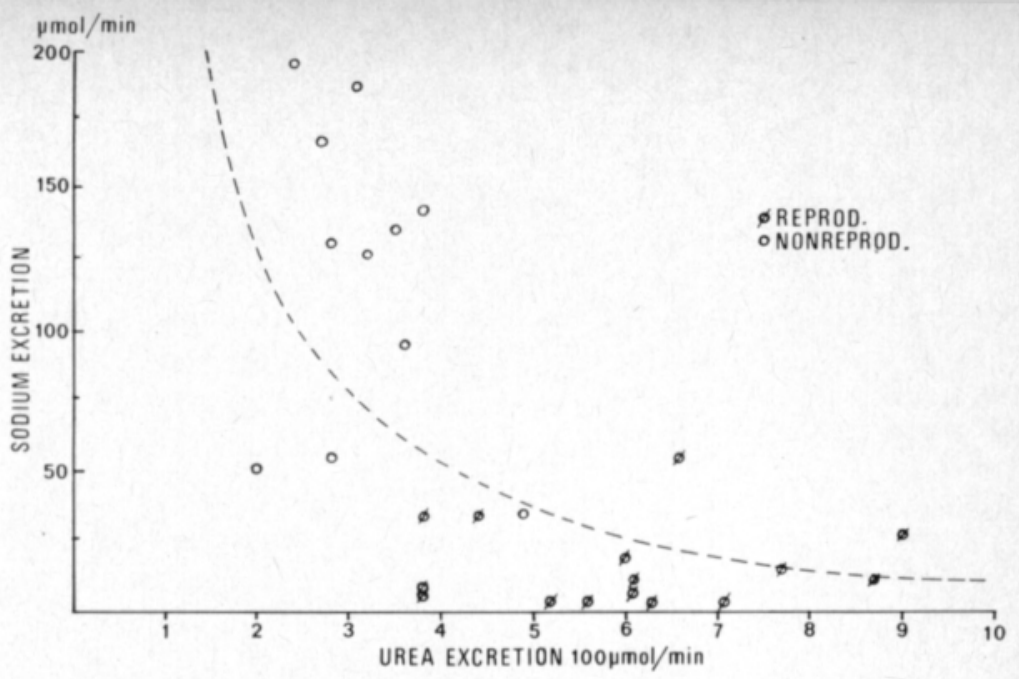

Fig. 9. Relationship between sodium and urea excretion rates on the $\mathrm{HP}$ diet with $\mathrm{NaCl}$ supplement, suggested to be described by the equation $y=\frac{28665}{x}-19.6, r=0.496$

Fig. 10. Flow rates and free water clearances showing the means \pm S.E.M. of 9 observations in the winter and 11 observations in the spring for four reindeer on the LP diet.

\section{Discussion}

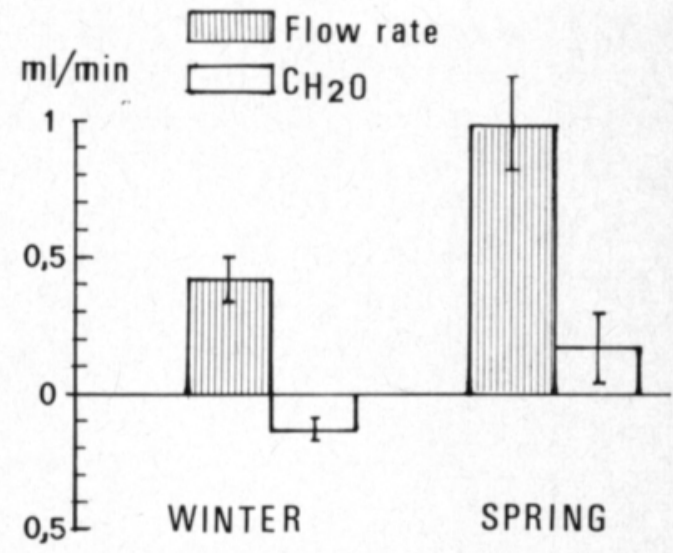

Marked changes in sodium and potassium excretion rates were seen in animals of both sexes during the autumn. The retention of electrolytes coincides with the breeding season of the reindeer which, according to Rorne (1974), in Finland commences in September. Some does may reach heat as late as the end of November or early December. The reindeer of this study showed signs of heat at the end of October and during November. The pronounced retention of electroiytes in the autumn presumably resulted from increased sex steroid to secretion during the breeding season. Estrogens and testosterone are known increase the retention of electrolytes and water from the tubules of the kidney (KATZ and Lindheimer 1977). They also promote growth of bones entailing the deposition of increased amounts of bone matrix with subsequent retention of calcium and phosphate. Increased retention of electrolytes in the skeleton in the autumn may be beneficial to reindeer with a winter diet poor in minerals.

No definite retention of water could be observed in the autumn during the nitrogen and sodium load, however, on the LP diet water excretion was significantly higher in the spring than in the winter, making the values of free water clearances positive. This is consistent with the observation of CAMERON and 
LuICK (1972) that water flux rates of reindeer decrease in the early winter and are high late in the spring. They also found higher total body water values in the winter than in the summer. These changes have been ascribed to differences in diet (LuIck et al. 1973/74). The results in this study, however, indicate that the cyclicity of reindeer metabolism may partly be due to hormonal readjustments accmopanying the breeding season.

McEwAN and WhiteheAd (1970) have noted a marked increase in nitrogen retention during the rutting time. Androgens are known to have an anabolic effect, but no clear retention of urea could be demonstrated in the present study. The strong retention of sodium may have masked it, since there is an interaction between sodium and urea excretion in the kidney, here described by a hyperbola (Fig. 9). Supposedly on the HP diet without salt the nitrogen retention would have been demonstrable.

\section{General evaluation of urea conservation}

In this study blood urea concentrations reflected the alterations in dietary protein intake when the energy intake was sufficient, but when the energy requirement was increased, the blood urea values on the low protein diet rose as a consequence of increased protein catabolism. Definite renal conservation of urea was demonstrable in either cases on restricted protein intake. It is now justified to verify the relationship between blood urea concentrations and the renal parameters in the whole material.

The urea excretion rates and urea clearances were positively related to plasma urea concentrations. Still, these parameters were lower on the lichen and LP-LE diets than on the HP diet, although the plasma urea concentrations had increased (Fig. 11 and 12). The fraction of filtered urea reabsorbed

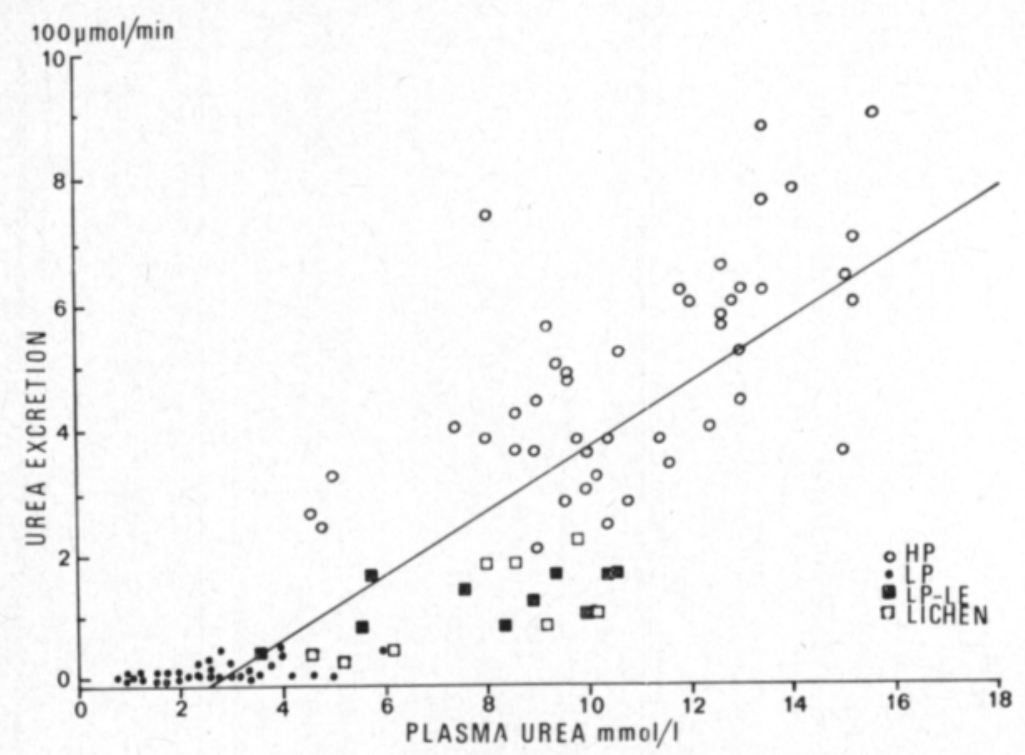

Fig. 11. Relationship between urea excretion rates and plasma urea concentrations on high protein (HP), low protein (LP), low protein low energy (LP-LE) and lichen diets the regression equation is $y=49.87 x-122.22$ and $r=0.871$. 


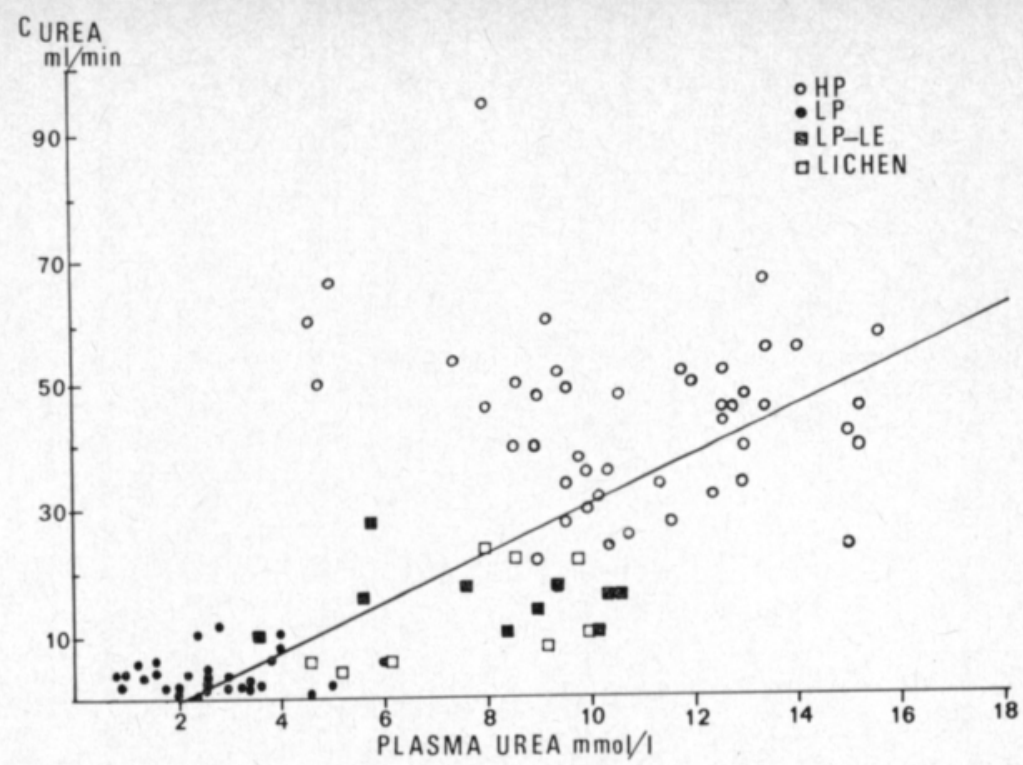

Fig. 12. Relationship between plasma urea concentrations and urea clearances on HP, LP, LP-LE and lichen diets. The regression equation is $\mathrm{y}=3.473 \mathrm{x}-0.905$ and $\mathrm{r}=0.696$. Diets marked as in Fig. 11.

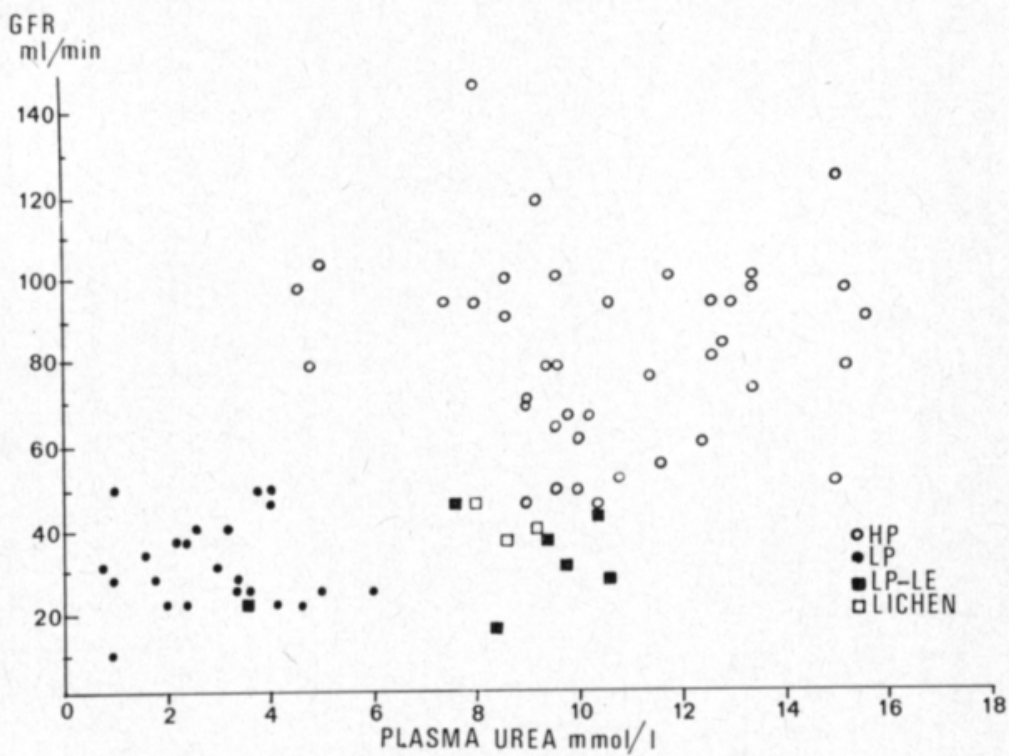

Fig. 13. GFR plotted as a function of plasma urea concentrations on HP, LP, LP-LE and lichen diets. Diets marked as in Fig. 11.

had decreased when plasma urea concentrations rose, but the GFR stayed low. The GFR, which was significantly higher on the HP diet than on the LP diet (Fig. 13), seems to be independent of plasma urea concentrations, but is in some way regulated by the intake of dietary protein. On the contrary, the percentage of reabsorbed urea is negatively correlated to plasma urea and to urea $\mathrm{U} / \mathrm{P}$ ratios (Fig. 14 and 15). 


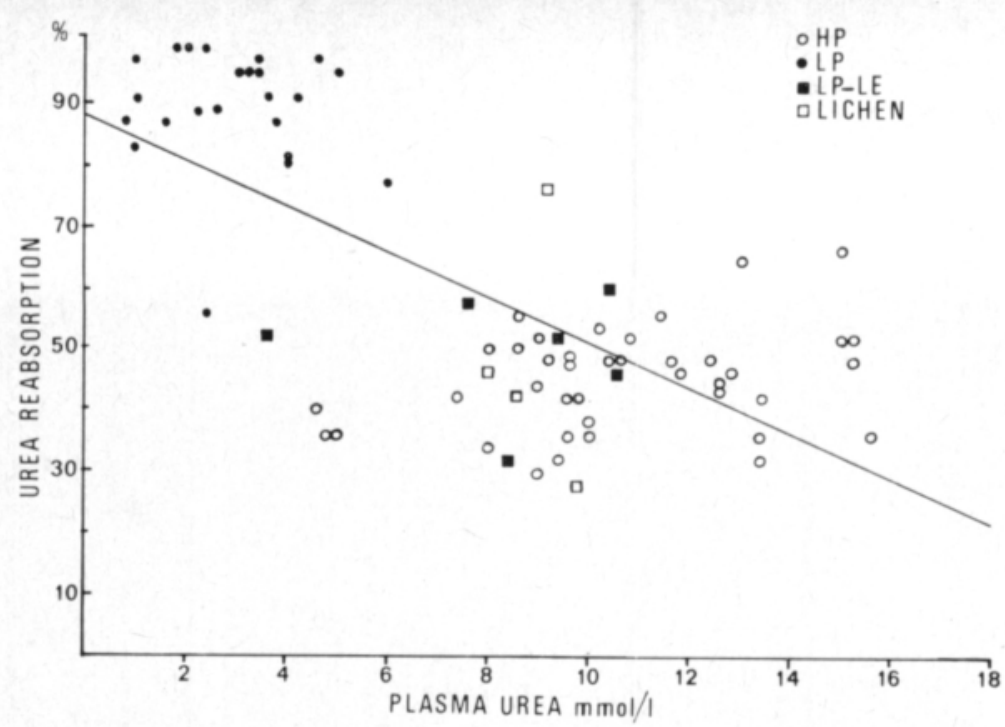

Fig. 14. Relationship between the percentages of filtered urea reabsorbed and plasma urea concentrations on HP, LP, LP-LE and lichen diets. The regression equation is $\mathrm{y}=-3.825 \mathrm{x}+89.2$ and $\mathrm{r}=-0.708$. Diets marked as in Fig. 11.

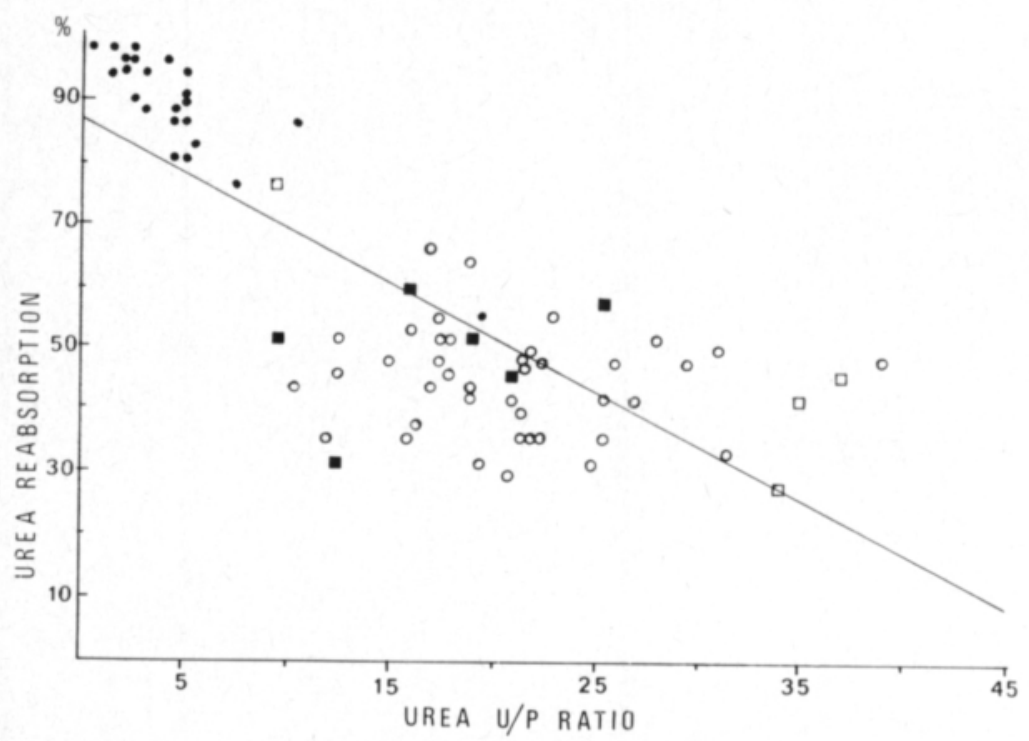

Fig. 15. Relationship between the percentages of filtered urea reabsorbed and urea urine to plasma $(\mathrm{U} / \mathrm{P})$ concentration ratios on $\mathrm{HP}$, LP, LP-LE and lichen diets. The regression equation is $\mathrm{y}=-1.724$ $\mathrm{x}+86.9$ and $\mathrm{r}=-0.747$. Diets marked as in Fig. 11.

There is abundant evidence of the fall of the GFR in ruminants on decreased dietary protein intake (Gans and Mercer 1962; McIntyre and Williams 1970; Ide 1971; Rabinowitz et al. 1973; Phillips et al. 1974; Ergene and Pickering 1978 b). Still, it has not been generally accepted as a definite 
renal response to protein restriction, nor has its significance to urea conservation been considered.

Renal plasma flow (RPF) that has been noted to decrease on low protein diet in sheep accompaning the decrease of the GFR (GANs and Mercer, 1962; Rabinowitz et al. 1973; Ergene and Pickering 1978 b), was not measured in the present study. The changes in the GFR are presumably associated with changes in the RPF, but the relation is not unconditional since, according to the study of Ergene and Pickering (1978 b), an elevated intake of sodium chloride on low protein diet may increase the RPF without affecting the GFR.

The mechanism whereby a change in dietary protein intake brings about the changes in renal function has received little attention. In the present work the changes in the GFR were independent of plasma urea concentrations. Similar conclusions can be drawn from studies on dogs, whose GFR can be increased by feeding meat (Shannon et al. 1932). O'Connor and Summerhill (1976 a, b) observed that an increase in the GFR caused by a protein rich meal could not be reproduced with urea given by stomach tube. On the other hand, a four-hour intravenous infusion of urea in sheep failed to influence the GFR on low protein diet (ERgene and Pickering, 1978 a). Instead, it was suggested that changes in the GFR are associated with changes in the quantity of protein passing to the abomasum and small intestine. RABINowitz at al. (1913) have discussed the possible effect of plasma levels of amino acids on kidney metabolism, but further work is required to clarify how the changes in the GFR are brought about.

The increased reabsorption of urea in ruminants and even other mammals has encouraged SchmidT-Nielsen and collaborators to profuse work in order to evince an active component in the urea transport in collecting ducts (ScHMIDTNielsen et al. 1958; Murdough et al. 1958; Truniger and Schmidt-Nielsen 1964; Ullarich et al. 1967). Increased permeability of collecting ducts on low protein diet has been suggested by RaBinowitz et al. (1973) and active transport of urea by the thick ascending portion of Henle's loop by Gavs (1976). However, although micropuncture studies point to the collecting duct as the locus of the increased reabsorption on low protein diets (JopPICH and DEETJEN 1971), no definite proof of active urea transport in renal tubules has been found. The result of the present work that the urea reabsorption decreased along with the increase of plasma urea concentrations is compatible with the passive movement of urea, even when the urea $\mathrm{U} / \mathrm{P}$ ratios decreased on the low protein diet.

The recycling of endogenous urea to rumen is of great importance in ruminants, since rumen microbes use ammonia as the primary nitrogenous nutrient for growth and protein synthesis. Cocimano and Leng (1967) have shown that sheep on low protein intake degraded a greater percentage of the endogenous urea than animals on high protein diet. Thus quantities of urea nitrogen returned to the rumen are especially significant in the nitrogen economy of animals fed low protein diets (Houpt 1970). In the present study, there was a highly significant correlation of plasma urea and rumen ammonia concentrations indicating that plasma urea is readily returned to the rumen (Fig. 16). Observations of Hobson (1970) of rumen ammonia in reindeer and WaLES 


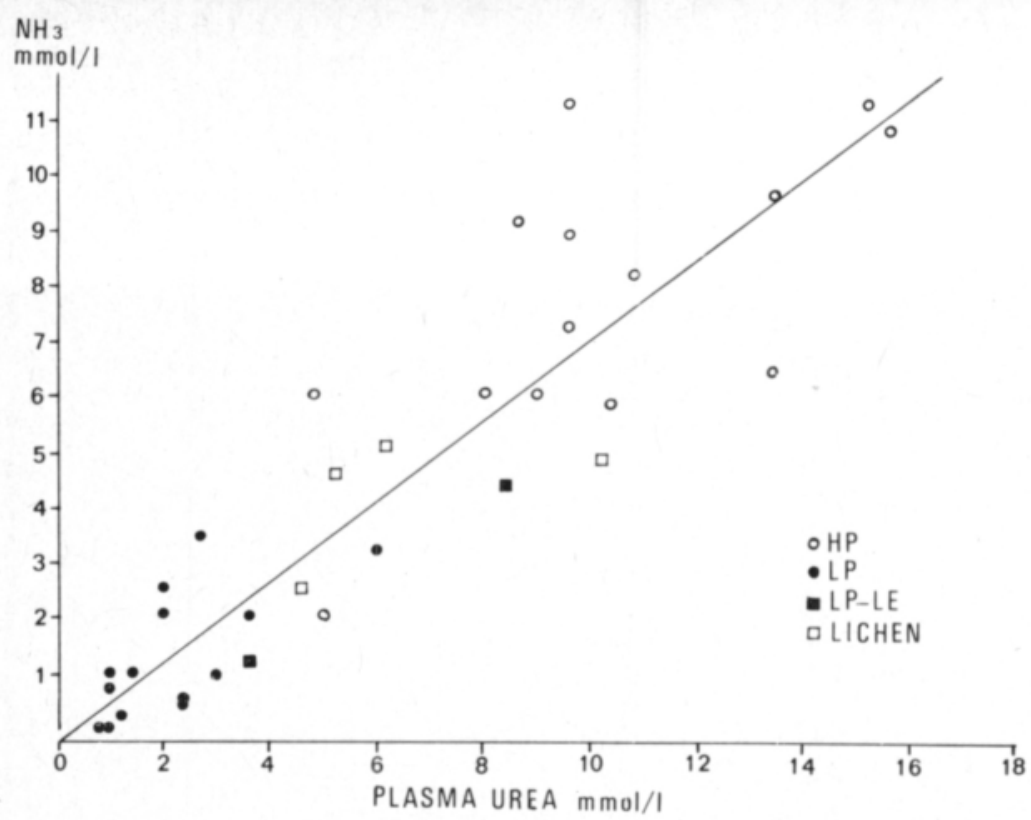

Fig. 16. Relationship between rumen ammonia and plasma urea concentrations on HP, LP, LP-LE and lichen diets. The regression eguation is $\mathrm{y}=102.3 \mathrm{x}+51.9$ and $\mathrm{r}=0.865$. Diets marked as in Fig. 11.

et al. (1972) of urea transferance between plasma and rumen in reindeer, cattle and sheep, suggest that reindeer may have a greater potential to recycle urea than do the typical domestic species of ruminants. The results of the present work indicate that also the capacity to conserye urea is very effective in reindeer. Restriction of urinary losses of urea, which is brought about by the reduction of GFR together with an increase in urea reabsorption, markedly contributes to the nitrogen economy of reindeer.

\section{REFERENCES}

Afanasev, V. P. 1964. Seasonal changes in the composition of reindeer blood. Trudy Vsesojunznogo Instituta Eksperimentalnyi Veterinarii 30: 205-212.

BAILEY, C. B. 1978. Renal function in cows given native grass hay containing added sodium chloride and rapeseed meal, with particular reference to the clearance of silicic acid. Can. J. Anim. Sci. 58: 651-657.

Berliner, R. W. 1976. The concentrating mechanism in the renal medulla. Kidney Int. 9: $214-222$.

Berlyne, G. M., Varley, H., Nilwarangkur, S. \& Hoerni, M. 1964. Endogeno uscreatinine clearance and glomerular-filtration rate. Lancet 24: 874-876.

Biddle, G. N. \& Evans, J. L. 1973. Nitrogen utilization in cattle using a nitrogen depletionrepletion technique. J. Anim. Sci. 36:123-129.

Cameron, R. D. \& Luick, J. R. 1972. Seasonal changes in total body water, extracellular fluid, and blood volume in grazing reindeer. Can. J. Zool. 50: 107-116.

Chaney, A. L. \& Marbach, E. P. 1962 . Modified reagents for determination of urea and ammonia. Clin. Chem. 8:130-132. 
CLAPP, J. R. 1966. Renal tubular reabsorption of urea in normal and protein depleted rats. Amer. J. Physiol. 210: 1304-1308.

Cocimano, M. R. \& Leng, R. A. 1967. Metabolism of urea in sheep. Br. J. Nutr. 21:353-371.

Dieterich, R. A. \& Luick, J. R. 1971. Reindeer in biomedical research. Lab. Anim. Sci. 21: $817-824$.

Ergene, N. \& Pickering, E. C. 1978 a. The effects of urea infusion on glomerular filtration rate and renal plasma flow in sheep fed low and high protein diets. Quart. J. Exp. Phys. 63: 77-81.

- \& Pickering, E. C. 1978 b. The effects of reducing dietary nitrogen and of increasing sodium chloride intake on urea excretion and reabsorption and on urine osmolality in sheep. Quart. J. Exp. Phys. 63: 67-76.

Eriksson, L. \& VALtonen, M. 1974. Seasonal changes in renal urea concentration in the reindeer (Rangifer tarandus L) Ann. Zool. Fenn. 11: 200-203.

FARrell, D. J., Leng, R. A. \& Corbett, J. L. 1972. Undernutrition in grazing sheep I. Changes in the composition of the body, blood, and rumen contents. Aust. J. Agric. Res. 23: $483-497$.

Gamble, J. L., McKhann, C. F. \& Butler, A. M. \& Tuthill, E. 1934. An economy of wates in renal function referable to urea. Amer. J. Physiol. 109: 139-154.

Gans, J. H. 1966. Renal excretion of urea in sheep. Amer. J. Vet. Res. 27:1279-1283.

- \& Mercer, P. F. 1962. Effect of osmotic diuresis and vasopressin on renal function in the sheep. Amer. J. Vet. Res. 23: 230-234.

Harmeyer, J., Varaby, J. \& Birck, R. 1973 Kinetische Parameter des Harnstoff-Stoffwechsels kleiner Wiederkäuer bei Fütterung und bei Hunger. Arch. Tierernährung 23: $461-481$.

Henrikx, A. \& Epstein, F. H. 1958. Effect of feeding protein and urea on renal concentrating ability in the rat. Amer. J. Physiol. 195: 539-542.

Hobson, P. N. 1970. Some field experiments on the rumen functions of red deer, hill sheep and reindeer. Deer 2: 450-452.

Houpt, T. R. 1959. Utilization of blood urea in ruminants. Amer. J. Physiol. 197: 115-120.

- 1970. Transfer of urea and ammonia to the rumen. In physiology of digestion and metabolism in the ruminant. Ed. by A. T. Phillipson. Oriel Press, p. 113-131. Newcastle.

Hove, K. \& Jacobsen, E. 1975. Renal excretion of urea in reindeer, effect of nutrition. Acta Vet. Scand. 16: 513-519.

Hungate, R. E. 1966. The rumen and its microbes. Academic Press., 533 p. New York.

Hyvärinen, H., Helle, T., Nieminen, M., Väyrynen, P. \& Väyrynen, R. 1976. Some effects of handling reindeer during gatherings on the composition of their blood. Anim. Prod. 22: 105-114.

- , Helle, T., Nieminen, M., Väyrynen, P. \& VÄYrynen, R. 1977. The influence of nutrition and seasonal conditions on mineral status in the reindeer. Can. J. Zool. 55: $648-655$.

- , Helle, T., Väyrynen, R \& VäYrynen, P. 1975. Seasonal and nutritional effects on serum proteins and urea concentration in the reindeer (Rangifer tarandus tarandus L.). Br. J. Nutr. 33: 63-72.

IDE, Y. 1971. Observations on plasma urea turnover and renal urea excretion in goats. Jap. J. Vet. Sci. 33: 179-185.

- , Shimbayashi, K. \& Yonemura, T. 1967. Effect of dietery conditions upon serum and milk-urea nitrogen in cows. II. Effect of low energy diets. Jap. J. Vet. Sci. 29: $33-39$.

Imbert, M. \& de Rouffignac, C. 1976. Role of sodium and urea in the renal concentrating mechanism in Psammamys obesus. Pflügers Arch. 361: 107-114.

Jamison, R. L. \& Maffly, R. H. 1976. Physiology in medicine. The urinary concentrating mechanism. New Engl. J. Med. 295: 1059-1067.

Joppich, R. \& DeEtJEN, P. 1971. The relation between the reabsorption of urea and of water in the distal tubule of the rat kidney. Pflügers Arch. 329:172-185.

Junasz, B. 1965. Endogenous nitrogen cycle in ruminants. Acta Vet. Hung. 15: 25-34.

Katz, A. L. \& Lindheimer, M. D. 1977. Actions of hormones on the kidney. Ann. Rev. Physiol. 39: $97-133$. 
Кокко, J. P. \& ReстоR, F. C. 1972. Countercurrent multiplication system without active transport in inner medulla. Kidney Int. 2: 214-223.

KUHN, W. \& RYFFEL, K. 1942. Herstellung konzentrierter Lösungen aus verdünnten durch blosse Membranwirkung: ein Modellversuch zur Funktion der Niere. Z. Physiol. Chem. 276: $145-178$.

Ladd, M., Liddele, L., Gagnon, J.A. \& Clarke, R. N. 1957. Glomerular and tubular functions in sheep and goats. J. Appl. Physiol. 10: 249-255.

Leibholz, J. 1970. The effect of starvation and low nitrogen intakes on the concentration of free amino acids in the blood plasma and on the nitrogen metabolism in sheep. Aust. J. Agric. Res. 21: 723-734.

LEVINSKY, N. G. \& BERLINER, R. W. 1959. The role of urea in the urine concentrating mechanism. J. Clin. Invest. 38: 741-748.

Livingston, H. G., PAyne, W. J. A., \& Friend, M. T. 1962. Urea excretion in ruminants. Nature 194: 1057-1058.

Luick, J. R., White, R. G., Cameron, R. D. \& Holleman, D. F. 1973/1974. The role of body water and nutrient recycling in the adaptation on Rangifer to life in the Arctic. Nutrition and metabolism of reindeer and caribou in Alaska. Progress Report. U.S.A. AEG. p. 74-94.

MacFArLANe, M. V. 1970/71. Water regulation in arctic ruminants. Nutrition and metabolism of reindeer and caribou in Alaska. Prog. Rep. U. S. A. AEG. p. 40-41.

Malory, G. M. O. \& Scotr, D. 1969. Renal excretion of urea and electrolytes in sheep and red deer. J. Physiol. 205: 91-101.

Manitius, A., Pigeon, G. \& Epstein, F. H. 1963. Mechanism by which dietary protein enhances renal concentrating ability. Amer. J. Physiol. 205: 101-106.

Manston, R., Russell, A. M., Sally, M. D. \& Payne, J. M. 1975. The influence of dietary protein upon blood composition in dairy cows. Vet. Rec. 96: 497-502.

Marlow, C. G. \& Sheppard, G. 1970. $\left[{ }^{51} \mathrm{Cr}\right]$ Edta, [Hydroxymethyl $\left.{ }^{14} \mathrm{C}\right]$ inulin and inulin $\mathrm{T}$ for the determination of glomerular filtration rate. Clin. Chim. Acta 28: 479-488.

Martinez-Maldonado, M. \& Opava-Stitzer, S. 1978. Urine concentration and dilution in the rat: Contribution of papillary structures during high rates of urine flow. Kidney Int. 13: $194-200$.

McCullough, H. 1967. The determination of ammonia in whole blood by a direct colorimetric method. Clin. Chim. Acta 17: $297-304$.

McDonald, I. W. 1948. The absorption of ammonia from the rumen of the sheep. Biochem. J. 42: $584-587$.

McEwan, E. H. 1958. Hematological studies of barren-ground caribou. Can. J. Zool. 46: $1031-1036$.

- \& Whitehead, P. E. 1970. Seasonal changes in the energy and nitrogen intake in reindeer and caribou. Can. J. Zool. 48: 905-913.

McIntyre, K. H. \& Williams, V. 1970. The role of the kidney in nitrogen conservation in sheep. Aust. J. Exp. Biol. Med. Sci. 48: 81-91.

Murdaugh Jr. H. V., Schmidt-Nielsen, B., Doyle, E. M. \& O'Dell, R. 1958. Renal tubular regulation of urea excretion in man. J. Appl. Physiol. 13: 263-268.

Nordfelt, S., Gagel, W. \& Nordqvist, M. 1961. Smältbarhetsförsök med renar i Öjebyn. Kungl. Lantbr.högsk. och Stat. Lantbr.för., Stat. Husdjursförsök, Förhandsmedd. 151: $1-4$.

O'Connor, W. J. \& Summerhill, R. A. 1976 a. The effect of a meal of meat on glomerular filtration rate in dogs at normal urine flows. J. Physiol. 256: 81-91.

- \& Summerhill, R. A. 1976 b. The excretion of urea by dogs following a meat meal. J. Physiol. 256: 93-102.

PERsson, H. 1969. Renens näringsbehov och renbetesväxternas näringsinnehåll. Rennäringsnytt 3:6-9.

Persson, S. 1967. Rennäringen. Studier av renarnas energibehov, Kgl. Lantbruksstyrelsen, Medd. B, 75. p. 1-23. Solna.

Phillips, G. D., Pickering, E. C. \& Wilkinson, K. 1974. Renal responses of the cow to alteration of the dietary intake of nitrogen and sodium chloride. J Physiol. 245: 95-96. 
Pickering, E. C. 1965. The role of the kidney in sodium and potassium balance in the cow. Proc. Nutr. Soc. 24: $73-80$.

PoIJÄRvI, I. 1945. Jäkäläruokinnalla olevien porojen jäkälän kulutus syksystä kevääseen. Valt. Maatal.toimik. Tied. 205: 1-10.

Potter, B. J. 1961. The renal response of sheep to prolonged ingestion of sodium chloride. Aust. J. Agric. Res. 12: 440-445.

Poulsen, E. 1957. Renal clearance in the cow. Veter. og Landbhøsk. Årsskr. p. 97-100.

Preston, R. L., Schnakenberg, D. D. \& Pfander, W. H. 1965. Protein utilisation in ruminats. 1. Blood urea nitrogen as affected by protein intake. J. Nutrition $86: 281-288$.

Rabinowitz, L., Gunther, R. A., Shoji, E. S., Freedland, R. A. \& Avery, E. H. 1973. Effects of high and low protein diets on sheep renal function and metabolism. Kidney Int. 4: $188-207$.

ReAD, B. E. 1925. Chemical constituents of camels's urine. J. Biol. Chem. 64:615-617.

RoINE, K. 1974. Studies on reproduction in female reindeer, with special referance to morphological and physiological conditions and foetal development. Thesis Coll. Vet. Med. 58 p. Helsinki.

de Rouffignac, C. \& Morel, F. 1969. Micropuncture study of water, electrolytes and urea movements along the loops of Henle in Psammomys. J. Celin. Invest. 48: 474-486.

Schmidt-Nielsen, B. \& O'Dell, R. 1959. Effect of diet on distribution of urea and electrolytes in kidneys of sheep. Amer. J. Physiol. 197: 856-860.

- \& O'DeLL, R. 1961. Structure and concentrating mechanism in the mammalian kidney. Amer. J. Physiol. 200: 1119-1124.

- , O'DeLL, R. \& OsAKI, H. 1961. Interdependence of urea and electrolytes in production of a concentrated urine. Amer. J. Physiol. 200: 1125-1132.

- , Osaki, H., Murdaygh Jr. H. V. \& O'Dell, R. 1958. Renal regulation of urea excretion in sheep. Amer. J. Physiol. 194: 221-228.

- \& Robinson, R. R. 1970. Contribution of urea to urinary concentrating ability in the dog. Amer. J. Physiol. 218: 1363-1369.

- , Schmidt-Nielsen, K., Jarnum, S. A. \& Houpt, T. R. 1957. Urea excretion in the camel. Amer. J. Physiol. 188: 477-484.

ScotT, D. \& MAson, G. D. 1970. Renal tubular reabsorption of urea in sheep. Quart. J. Exp. Physiol. 55: 275-283.

Sellers, A. F., Pritchard, W. R., Weber, A. F. \& Sautter, J. H. 1958. Renal function studies on normal dairy cattle and those with postparturient albuminuria. Amer. J. Vet. Res. 19: $580-584$.

Shannon, J. A., Jolliffe, N \& Sмith, H. W. 1932. The excretion of urine in the dog. IV. The effect of maintenance diet, feeding, etc. upon the quantity of glomerular filtrate. Amer. J. Physiol. 101: 625-638.

- \& Sмrтн, H. W. 1935. The excretion of inulin xylose, and urea by normal and phlorhizinized man. J. Clin. Invest. 14: 393-401.

Sjenneberg, S. \& Slagsvold, L. 1968. Reindriften og dens naturgrunlag, Universitetsforlaget, 332 p. Oslo.

Sperber, C. \& Sperber, I. 1955. Observations on creatinine excretion in ruminants. Kgl. Lantbrukshögskolans Ann. 22: 125-130.

SPERBER, I. 1944. Studies on the mammalian kidney. Zool. Bidr. Uppsala 22: 249-431.

STEEN, E. 1968. Some aspects of nutrition of semi-domestic reindeer. In comparative nutrition of wild animals. ed. Grauford, M. A. Academic Press. p. 117-128. London-New York.

Teeri, A. E., Virchow, W., Colovos, N. F. \& Greeley, F. 1958. Blood composition of deer. J. Mammal. 39: 269-274.

Thurau, K., Valtin, H. \& Schnermann, J. 1968. Kidney. Tubular transport of organic compounds. Ann. Rev. Physiol. 30: 469-477.

Topps, J. H. \& ElLiot, R. C. 1967. Partition of nitrogen in the urine of African sheep given a variety of low-protein diets. Anim. Prod. 9:219-227.

Truniger, B. \& Schmidt-Nielsen, B. 1964. Intrarenal distribution of urea and related compounds: effects of nitrogen intake. Amer. J. Physiol. 207: 971-978. 
Ullrich, K. J., Rumrich, G. \& Schmidt-Nielsen, B. 1967. Urea transport in the collecting duct of rats on normal and low protein diet. Pflügers Arch. ges. Physiol. 295: 147156.

VALTONEN, M. \& ERIKsson, L. 1977. Responses of reindeer to water loading, water restriction and ADH. Acta Physiol. Scand. 100: $340-346$.

VoGEL, G. 1962. Beiträge zur Kenntnis der Nierenphysiologie einiger Haussäugetiere. Zbl. Vet. Med. Supp. 3. p. 53.

Wales, R. A., Milligan, L. P. \& McEwan, E. H. 1972. Urea recycling in caribou, cattle and sheep. Proc. Ist. Int. Reindeer/Caribou Symp. Fairbanks, Alaska. p. 297-307.

WeEth, H. J. \& Lesperance, A. L. 1965. Renal function of cattle under various water and salt loads. J. Anim. Sci. 24: 441-447.

Helsinki, September 1979

\title{
SELOSTUS
}

\section{Rehun raakavalkuais- ja suolapitoisuuden vaikutus poron munuaistoimintaan}

\author{
Maija Valtonen \\ Eläinlääketieteellinen korkeakoulu, fysiologian laitos ja Helsingin yliopisto, eläinlääketieteen laitos
}

Poron elinympäristōn olosuhteet vaihtelevat huomattavasti vuodenaikojen mukaan. Kesän aikana poro saa riittävästi täysipainoista ravintoa, jonka energia- ja valkuaispitoisuus tyydyttää eläimen tarpeet. Talvella poro joutuu turvautumaan pääasiassa jäkälään. Jäkälä sisältää runsaasti energiaa, mutta sen valkuais- ja kivennäispitoisuus on erittäin alhainen. Talven aikana poron elimistö joutuu säästämään typpeä ja suoloja vähentämällä niiden eritystä virtsaan.

Tässä tutkimuksessa on selvitetty poron munuaisen toimintaa ja kykyä säästää typellisiä aineita ja suoloja runsaalla ja niukalla valkuaisruokinnalla suolan $(\mathrm{NaCl})$ saannin vaihdellessa. Tutkimuksessa käytettiin yhteensä kymmentä poroa. Runsaalla valkuaisruokinnalla $(17 \%$ rv/ka) suoritettiin kaikkiaan 46 yksittäistä munuaisen toimintakoetta ja niukalla valkuaisruokinnalla $(3-4 \% \mathrm{rv} / \mathrm{ka}) 43$ koetta. Jäkäläruokinnalla tehtiin kahdeksan koetta. Kokeissa määritettiin veren ureapitoisuus, virtsan urean ja elektrolyyttien $(\mathrm{Na}, \mathrm{K})$ eritys, veden eritys sekä munuaiskerästen suodattamisnopeus. Lisäksi laskettiin suodattuneen, erittyneen ja takaisinimeytyneen urean määrä.

Runsaalla valkuaisruokinnalla veren ureapitoisuus oli korkea (keskimäärin $11 \mathrm{mmol} / 1$.) Myös urean eritys virtsaan oli runsasta (keskimäärin $478 \mu \mathrm{mol} / \mathrm{min}$ ). Lisäksi virtsan eritysnopeus kasvoi. Munuaiskerästen suodattamisnopeus oli suuri, urean takaisinimeytyminen munuaistiehyeistä oli puolestaan vähäistä. Niukalla valkuaisruokinnalla plasman ureapitoisuus laski keskimäärin arvoon $3 \mathrm{mmol} / 1$. Samalla virtsan eritysnopeus ja ureapitoisuus vähenivät huomattavasti. Munuaiskerästen suodattamisnopeus laski noin kolmanteen osaan ja suodattuneen urean määrä kymmenenteen osaa verrattuna runsaaseen valkuaisruokintaan. Urean takaisinimeytyminen lisääntyi voimakkaasti ollen noin $90 \%$ suodattuneesta määrästä. Suodattamisnopeuden pieneneminen oli kuitenkin merkittävin muutos munuaistoiminnassa urean erityksen vähentämiseksi -

Suolan lisääminen rehuun aiheutti natriumin erityksen ja virtsan osmoottisen väkevyyden nousun. Runsaalla valkuaisruokinnalla lisääntyneeseen natriumeritykseen liittyi urean erityksen väheneminen. Tämä vuorovaikutus ilmeni erityisen selvästi syksyllä kiima-aikana, jolloin elektrolyyttien ja veden erittyminen väheni palautuen ruokinnan edellyttämälle tasolle vasta kiima-ajan loputtua.

Porot joivat vettä keskimäärin 2.7 1/vrk niukalla valkuaisruokinnalla. Runsaalla valkuaisruokinnalla juomaveden kulutus kasvoi kaksinkertaiseksi ollen keskimäärin $5.7 \mathrm{l} / \mathrm{vrk}$. Poron munuainen poikkeaa lehmän ja lampaan munuaisesta siinä, että sen ydinkerros on matala ja 
virtsan väkevöimiskyky heikko. Näinollen porot joutuvat runsaalla valkuaisruokinnalla juomaan huomattavasti enemmän voidakseen erittää ylimääräisen typen virtsaan. Sensijaan päivittäinen suolalisäys $(6-10 \mathrm{~g})$ ei vaikuttanut veden kulutukseen merkitsevästi. Suolalisäys ei myöskään vaikuttanut munuaiskerästen suodattamisnopeuteen.

Talvella tarhassa ulkolämpötilan laskiessa alle kymmenen pakkasasteen rehun energiamäärä niukalla valkuaisruokinnalla ei täyttänyt ylläpitotarvetta, vaan porot laihtuivat. Elimistôn valkuaisaineiden käyttöä energiatarpeen tyydyttämiseksi seurasi veren ureapitoisuuden nousu. Samalla myös virtsan ureapitoisuus kasvoi. Munuaiskerästen suodattamisnopeus pysyi kuitenkin alhaisella tasolla vähentäen urean menetystä virtsaan. Suodattamisnopeus ei ilmeisesti ole riippuvainen veren ureapitoisuudesta, vaan seuraa ruokinnan valkuaispitoisuutta. Sensijaan urean takaisinimeytyminen väheni veren ureapitoisuuden noustessa. Tämä tukee teoriaa urean passiivisesta siirtymisestä konsentraatioeron mukaisesti myös märehtijöiden munuaisessa.

Jäkäläruokinnalla porojen rehun syöntimäärä ei myöskään riittänyt täyttämään ylläpitoenergian tarvetta, vaan porot laihtuivat ja veren ureapitoisuus nousi. Urean eritysnopeus virtsaan pysyi kuitenkin alhaisena, koska munuaiskerästen suodattamisnopeus ei noussut. Jäkälän suhteellisen suuri vesipitoisuus $(48-64 \%)$ lisäsi veden eritystä. Tämä ei kuitenkaan aiheuttanut suolojen eikä urean lisääntynyttä menetystä virtsaan.

Pötsinesteen ammoniakkipitoisuus oli merkitsevästi $(\mathrm{p}<0.001)$ riippuvainen veren ureapitoisuudesta. Tämä osoittaa poron veren kulkeutuvan pötsiin varsin helposti. Urean erityksen väheneminen rehun valkuaispitoisuuden laskiessa on tärkeää märehtijän typpitaloudelle.

Poron munuainen on tässä tutkimuksessa osoittautunut heikosta virtsan väkevöimiskyvystään huolimatta tehokkaaksi säästämään ureaa. Valkuaisen saannin ollessa niukkaa suodattuminen vähenee munuaisessa. Lisäksi urean takaisinimeytyminen lisääntyy, jos energian saanti on riittävää ja veren ureapitoisuus pysyy alhaisena. 